\title{
Postępowania karne prowadzone w latach 1947-1955 w sprawach przestępstw okupacyjnych popełnionych przez policjanta granatowego Jana Błażeja. Przyczynek do badań nad stosunkami polsko-żydowskimi
}

„Po wojnie ten «bohater», który był postrachem całej okolicy w czasie okupacji hitlerowskiej, zniknął, gdzieś się zaszył, wyczekując dla siebie lepszych czasów, może jeszcze marzył o możliwości powrotu do okupacyjnego procederu”. Tak w swoich wspomnieniach Bernard Trawiński² opisywał oprawcę swojej siostry i jej rodziny, Jana Błażeja, jednego z policjantów granatowych pełniących podczas okupacji służbę na posterunku w Ruszczy ${ }^{3}$. Bernard Traub przeżył

1 B. Trawiński, Przeblyski czarnej nocy. Wspomnienia 1939-1945, Kraków 2011, s. 106.

2 Bernard Jan Trawiński (nazwisko rodowe Bernard Traub) ur. 5 listopada 1906 r. w Kościelnikach, gm. Ruszcza k/Krakowa. W 1931 r. uzyskał dyplom magistra prawa. W 1934 r. poślubił Helenę Marię z d. Neuger. Mieli dwoje dzieci: Krystynę (ur. 16 lipca 1936 r.) i Wojciecha (ur. 26 maja 1946 r.). W 1938 r. złożył egzamin adwokacki. W 1945 r. rozpoczął pracę w Prokuraturze Sądu Okręgowego w Krakowie. Od 1945 r. należał do PPs, następnie PZPR. Dnia 1 stycznia 1956 r. został zwolniony z prokuratury. 17 lutego 1958 r. wraz z rodziną wyjechał do Kanady. B. Trawiński, Przebłyski czarnej nocy..., dz. cyt., s. 7-12.

3 Gmina Ruszcza w czasie okupacji niemieckiej wchodziła w skład powiatu krakowskiego w dystrykcie krakowskim w Generalnym Gubernatorstwie. Amtliches Gemeinde- und Dorfverzeichnis für das Generalgouvernement auf Grund der Summarischen Bevölkerungsbestandsaufnahme am 1. März 1943, Krakau 1943, s. 23-25. 
zagładę i okres okupacji, ukrywając się w Proszowicach na aryjskich papierach jako Józef Kulpa. Po wojnie zmienił nazwisko na Trawiński ${ }^{4}$

Jego siostra Zofia Messinger ${ }^{5}$, jej mąż Leon ${ }^{6}$ i ich syn Józef 5 stycznia 1943 r. zostali zamordowani na cmentarzu w Ruszczy ${ }^{8}$. Według autora Przebłysków czarnej nocy w latach pięćdziesiątych odbył się proces sprawców tej egzekucji. Temat powojennego rozliczenia przestępstw okupacyjnych popełnionych przez niektórych policjantów granatowych wciąż pozostaje nieopracowany, dlatego zdecydowano się przeprowadzić poszukiwania źródłowe w sprawie powojennych postępowań karnych jednego z uczestników opisanej zbrodni ${ }^{9}$.

Pod koniec II wojny światowej, w celu ukarania przestępców wojennych i obywateli polskich ${ }^{10}$ współpracujących z okupantem, ustanowiono nowe przepisy $\mathrm{w}$ wewnętrznym prawie karnym, obejmujące specjalne przestępstwa okupacyjne $^{11}$. Władze komunistyczne 31 sierpnia 1944 r. wydały Dekret o wymiarze

4 B. Trawiński, Przebłyski czarnej nocy..., dz. cyt., s. 9-10.

5 Zofia vel Süssla z Traubów Messingerowa, ur. 23 grudnia 1903 r. w Kościelnikach, żona Leona, córka Samuela i Wiktorii z Weinrebów.

6 Leon Messinger, ur. 29 lipca 1904 r. w Krakowie, syn Hermana i Sary z Grossów.

7 Józef Messinger, ur. 17 maja 1932 r. w Krakowie, syn Leona i Zofii vel Süssla z Traubów.

8 Po wojnie ich ciała zostały ekshumowane i pochowane na cmentarzu żydowskim przy ul. Miodowej w Krakowie. Uratowała się ich córka Danusia (ur. 1938 r.), którą po wojnie przysposobił Bernard Trawiński. B. Trawiński, Przebłyski czarnej nocy..., dz. cyt., s. 11; ANK 29/I 2 Zg 1054/46, Pismo adwokata Feliksa Sileigera do Sądu Grodzkiego w Krakowie, Kraków [data wpływu 31.12.1946], k. 1; ANK 29/I 2 Zg 1054/46, Postanowienie o stwierdzenie zgonu Sądu Grodzkiego w Krakowie, Kraków, 4.01.1947, k. 3.

9 Jedyną monografią dotyczącą granatowej policji jest: A. Hempel, Pogrobowcy klęski. Rzecz o policji „granatowej” w Generalnym Gubernatorstwie 1939-1945, Warszawa 1990, s. 76-86. Ustaleń dotyczących negatywnych zachowań policjantów granatowych wobec ludności żydowskiej na obszarach wiejskich w dystrykcie krakowskim na podstawie akt procesów sierpniowych dokonał Jan Grabowski. Zob.: J. Grabowski, Strażacy, wiejska straż nocna i granatowa policja a zagłada Żydów na obszarach wiejskich $w$ dystrykcie krakowskim, [w:] Zagłada Żydów na polskiej prowincji, red. A. Sitarek, M. Trębacz, E. Wiatr, Łódź 2012, s. 245-264; J. Grabowski, Społeczność wiejska, policja granatowa i ukrywający się Żydzi: powiat Dąbrowa Tarnowska 1942-1945, [w:] Zarys krajobrazu. Wieś polska wobec zagłady Żydów 1942-1945, red. B. Engelking, J. Grabowski, Warszawa 2011, s. 139-170 (artykuł ten powstał w części na podstawie: J. Grabowski, Judenjagd. Polowanie na Żydów 1942-1945. Studium dziejów pewnego powiatu, Warszawa 2011).

10 Zmiany w polskim prawie karnym służyły również do zwalczania opozycji politycznej i walki z przeciwnikami nowego ustroju.

${ }^{11}$ Zgodnie z ostatecznym brzmieniem dekret określał następujące stany faktyczne przestępstw: 1) branie udziału w dokonywaniu zabójstw osób spośród ludności cywilnej albo osób wojskowych lub jeńców wojennych (art. 1 pkt 1 dekretu sierpniowego); 2) wskazanie lub ujęcie osób poszukiwanych lub 
kary dla faszystowsko-hitlerowskich zbrodniarzy winnych zabójstw i znęcania się nad ludnością cywilną i jeńcami oraz dla zdrajców Narodu Polskiego ${ }^{12}$.

We wrześniu 1944 r. powołano specjalne sądy karne do orzekania w sprawach przeciwko oskarżonym o przestępstwa zawarte w dekrecie z 31 sierpnia 1944 r. Dekretem z 17 października 1946 r. zlikwidowano specjalne sądy karne, przekazując ich kompetencje sądom okręgowym ${ }^{13}$. W latach od 1949 do 1950 zbrodnie określone $\mathrm{w}$ dekrecie sierpniowym rozpoznawały w pierwszej instancji sądy apelacyjne ${ }^{14}$, a od stycznia $1951 \mathrm{r}$. postępowania karne toczyły się przed sądami wojewódzkimi ${ }^{15}$.

prześladowanych ze względów politycznych, narodowościowych, wyznaniowych lub rasowych (art. 1 pkt 2 dekretu sierpniowego);3) działanie na szkodę państwa polskiego, polskiej osoby prawnej, osób spośród ludności cywilnej lub osób wojskowych albo jeńców wojennych, w inny sposób lub w innych okolicznościach niż przewidziane w art. 1 (art. 2 dekretu sierpniowego); 4) wymuszanie świadczeń pod groźbą wywołania prześladowań albo działanie w inny sposób na szkodę osób poszukiwanych lub prześladowanych (art. 3 dekretu sierpniowego); 5) branie udziału w organizacji przestępczej mającej na celu zbrodnie przeciwko pokojowi, zbrodnie wojenne lub zbrodnie przeciwko ludzkości (art. 4 dekretu sierpniowego). A. Pasek, Przestępstwa okupacyjne $w$ polskim prawie karnym z lat 1944-1956, Wrocław 2002, s. 40; E. Kobierska-Motas, Ekstradycja przestępców wojennych do Polski z czterech stref okupacyjnych Niemiec: 1946-1950, cz. 2, Warszawa 1992, s. 7; L. Kubicki, Zbrodnie wojenne $w$ świetle prawa polskiego, Warszawa 1963, s. 66-67; A. Rzepliński, Ten jest z ojczyzny mojej? Sprawy karne oskarżonych o wymordowanie Żydów w Jedwabnem w świetle zasady rzetelnego procesu, [w:] Wokół Jedwabnego, red. P. Machcewicz, K. Presak, t. 1: Studia, Warszawa 2002, s. 355-356; A. Lityński, O prawie i sądach początków Polski Ludowej, Białystok 1999, s. 63-64; J. Wojciechowska, Przestępcy hitlerowscy przed specjalnym sądem karnym w Toruniu (1945-1946), Toruń 1965, s. 16.

12 Dz.U. 1944 nr 4, poz. 16. Dekret sierpniowy był nowelizowany pięciokrotnie. Dz.U. 1945 nr 7, poz. 29; Dz.U. 1946 nr 69, poz. 376; Dz.U. 1947 nr 65, poz. 39o; Dz.U. 1948 nr 18, poz. 124; Dz.U. 1949 nr 32, poz. 238. W chwili obecnej pozostaje w mocy jedynie art. 1 pkt 1 dekretu, który ma charakter przepisu karnego szczególnego. R. Ignatiew, Komentarz do art. 1 pkt 1 dekretu $z$ dnia 31.08.1944 r. o wymiarze kary dla faszystowsko-hitlerowskich zbrodniarzy winnych zabójstw i znęcania się nad ludnością cywilna i jeńcami oraz dla zdrajców Narodu Polskiego (tekst jednolity Dz.U. 1946, nr 69, poz. 377, z późn. zm.), [w:] Zbrodnie przeszłości. Opracowania i materiały prokuratorów $I P N$, red. R. Ignatiew, A. Kury, t. 2: Ludobójstwo, Warszawa 2008, s. 104. Przepisy wprowadzające Kodeks karny z 1997 r. w miejsce sankcji w postaci kary śmierci wprowadziły karę dożywotniego pozbawienia wolności (art. 13 pkt 1 p.w.k.k.). Dz.U. 1997 nr 88, poz. 554.

${ }_{13}$ Zakres postępowania karnego przed tymi sądami został określony w Dekrecie z 13 czerwca 1946 r. o przestępstwach szczególnie niebezpiecznych w okresie odbudowy państwa (Mały kodeks karny).

${ }_{14}$ Na podstawie Ustawy z dnia 27 kwietnia 1949 r. o zmianie przepisów postępowania karnego (Dz.U. 1949 nr 32, poz. 238).

${ }_{15}$ Ustawa z 20 lipca 1950 r. o zmianie przepisów postępowania karnego (Dz.U. $1950 \mathrm{nr}$ 38, poz. 348) zniosła Sądy Grodzkie, a miejsce Sądów Okręgowych i Apelacyjnych zajęły Sądy Powiatowe i Sądy 
Kim byli podsądni, dawni policjanci granatowi, przeciw którym wszczęto analizowane postępowania? Polska policja od koloru mundurów nazywana granatową funkcjonowała już od jesieni $1939 \mathrm{r}^{16}$, a za formalną datę jej powołania uznaje się 17 grudnia 1939 r. Jej kadrę tworzyli głównie funkcjonariusze przedwojennej Polskiej Policji Państwowej. Policja granatowa funkcjonowała pod bezpośrednim nadzorem żandarmerii niemieckiej. Miała dwoisty charakter. Z jednej strony pełniła czynności administracyjno-porządkowe oraz służbę ogólnopolicyjną w zakresie ochrony porządku i bezpieczeństwa publicznego. Z drugiej strony była wykorzystywana przez Niemców do realizacji ich polityki okupacyjnej ${ }^{17}$. Do zadań policji granatowej wymierzonych przeciwko ludności żydowskiej należało: sprawdzanie dokumentów, przeprowadzanie rewizji, służba patrolowo-wartownicza wokół gett, wyłapywanie uciekających lub ukrywających się po stronie aryjskiej Żydów, udział w akcjach eksterminacyjnych poprzez ochronę miejsc egzekucji. Jak zauważyła Elżbieta Rączy, czasem zmuszano policjantów do rozstrzeliwania skazańców ${ }^{18}$.

Podstawowym celem niniejszego opracowania stało się zwrócenie uwagi na informacje, które występują w aktach powojennych postępowań karnych w sprawie przestępstw okupacyjnych popełnionych wobec ludności żydowskiej. Szczegółowo przedstawiona zostanie osoba sprawcy oraz temat ratowania Żydów. Ze względu na procesowy charakter analizowanego materiału w przypadku niektórych świadków zdecydowano się na niepodawanie ich nazwisk, ukrywając je pod inicjałami. Wyjątkiem będą nazwiska funkcjonujące już w literaturze przedmiotu.

Wojewódzkie. Sąd Apelacyjny mógł - na wniosek prokuratora - przekazać sprawę do rozpoznania Sądowi Okręgowemu. Taka sama kompetencja przysługiwała Sądowi Wojewódzkiemu w odniesieniu do Sądów Powiatowych.

${ }^{16}$ W dniu 30 października 1939 r. wyższy dowódca ss i Policji W. Krüger wydał odezwę, w której pod groźbą najsurowszych kar zobowiązał wszystkich funkcjonariuszy polskiej policji, jeśli znajdowali się w służbie czynnej w dniu 1 września 1939 r., do zgłoszenia się w najbliższym urzędzie Policji Niemieckiej lub w Starostwie Niemieckim. Odezwa Wyższego Dowódcy ss (Schutzstaffel) i Policji w Generalnym Gubernatorstwie dla okupowanych polskich obszarów $z$ dnia 30 października 1939 r., „Verordnungsblatt des generalgouverneurs für die besetzen polnischen Gebiete” (1939) nr 2, s. 16.

${ }^{17}$ A. Hempel, Pogrobowcy klęski..., dz. cyt., s. 76-86.

18 E. Rączy, Zagłada Żydów w dystrykcie krakowskim w latach 1939-1945, Rzeszów 2014, s. 46-47. 


\section{Sprawa o sygnaturze: $x$ Ds 304/47}

Pierwsze znane postępowanie w sprawie przestępstw dokonanych przez policjanta granatowego Jana Błażeja prowadzone było przez Prokuraturę Sądu Okręgowego w Krakowie pod sygnaturą akt x Ds 304/47. Bezpośredni impuls, który spowodował, że zostało ono wszczęte, był związany z zawiadomieniem skierowanym przez ówczesnego wiceprokuratora tegoż sądu Bernarda Trauba (Trawińskiego) ${ }^{19}$. Prokurator informował o rozstrzelaniu 5 stycznia $1943 \mathrm{r}$. ukrywającej się w Kościelnikach rodziny Messingerów (Leona, Zofii i ich synka Józefa) przez policjantów granatowych (nieznanych mu z imienia) Błażeja i Kosteczkę. Według prokuratora: „policjant N. Błażej został w jakiejś inne[j] sprawie ujęty i osadzony w areszcie w Sądzie grodzkim w Pruchniku [w Prudniku] - Dolny Śląsk" ${ }^{\prime \prime}$.

Prokuratura Sądu Okręgowego w Krakowie niezwłocznie podjęła pierwsze czynności. Prokurator skierował wnioski o zastosowanie tymczasowego aresztu i przesłuchanie byłego funkcjonariusza policji granatowej ${ }^{21}$. Według zawiadomienia skierowanego z więzienia w Prądniku więzień Błażej nie figurował w ich ewidencji ${ }^{22}$. W styczniu 1948 r. wiceprokurator Sądu Okręgowego w Krakowie S. Koniuszewski prosił Powiatową Komendę mo w Krakowie o ustalenie danych personalnych Błażeja i Kosteczki, byłych posterunkowych policji granatowej, zatrudnionych na posterunku w Ruszczy w 1943 r. Sprawę określono jako bardzo pilną ${ }^{23}$.

Posterunek Gminny mo w Ruszczy nie był w stanie ustalić danych personalnych poszukiwanych. Meldowano jedynie, że „przed wejściem wojsk

19 IPN Kr 502/3496, Pismo Wiceprokuratora Sądu Okręgowego Bernarda Trauba do Prokuratora Sądu Okręgowego w Krakowie, Kraków, 20.10.1947, k. 23.

${ }^{20}$ IPN Kr 502/3496, Pismo Wiceprokuratora Sądu Okręgowego Bernarda Trauba do Prokuratora Sądu Okręgowego w Krakowie, Kraków, 20.10.1947, k. 23.

${ }^{21}$ IPN Kr 502/3496, Pismo Prokuratury Sądu Okręgowego w Krakowie do Sędziego Okręgowego śledczego w Prudniku (Dolny Śląsk), Kraków, 20.10.1947, k. 26. Sąd Okręgowy w Nysie przesłał wniosek prokuratora Sądu Okręgowego w Krakowie dotyczący aresztowania i przesłuchania jako podejrzanego Błażeja do Sądu Grodzkiego w Prudniku. IPN Kr 502/3496, Pismo Sądu Okręgowego w Nysie z siedzibą w Prudniku do Prokuratury Sądu Okręgowego w Krakowie, [b.m.], 25.10.1947, k. 24 .

${ }^{22}$ IPN Kr 502/3496, Pismo Kierownika Działu Administracyjnego Więzienia w Prądniku do Sądu Grodzkiego w Pr[ą]dniku, Prądnik, [data wpływu: 3.11.1947], k. 32.

${ }^{23}$ IPN Kr 502/3496, Pismo Sądu Okręgowego w Krakowie do Powiatowej Komendy Milicji Obywatelskiej w Krakowie, Kraków, 14.01.1948, k. 43. 
sprzymierzonych W/W zbiegli z Posterunku Policji w Ruszczy a gdzie to tego niemożna ustalić" ${ }^{24}$. Jak wynika $\mathrm{z}$ kolejnych dokumentów postępowania dowodowego, poszukiwani nie złożyli podań o wszczęcie postępowania rehabilitacyjnego i ich adresy nie były znane Komisji Rehabilitacyjnej dla byłych funkcjonariuszach policji granatowej przy Prezydium Rady Ministrów ${ }^{25}$.

Pomimo braku efektów w poszukiwaniach podejrzanych funkcjonariusze posterunku mo w Ruszczy na polecenie ${ }^{26}$ prokuratury przesłuchali świadków w sprawie rozstrzelania rodziny Messingerów ${ }^{27}$. Dnia 21 czerwca 1948 r. Prokurator so w Krakowie na podstawie art. 188 k.p.k. zarządził inwigilację i poszukiwania za Józefem [błędnie podane imię] Błażejem i Kosteczką ${ }^{28}$.

W lutym 1949 r. do Komendy Mo w Wałbrzychu wpłynął meldunek Mariana Piskorza, funkcjonariusza Mo, w sprawie byłego granatowego policjanta „Błaszej[a] Jeż[ego]: [...] w/w był słynny w powiecie Krakowskim jak również ma dużo morderstw na sumieniu"29. Milicjant meldował, że poszukiwany mieszka w Wałbrzychu przy ul. Plac Wolności 2. Na podstawie tego meldunku Sekcja Śledcza mo w Wałbrzychu prosiła o ustalenie, ,jaką opinią cieszył się wymieniony w czasie okupacji niemieckiej"30. W ramach tego dochodzenia posterunek MO w Ruszczy przesłuchał kolejnych świadków. W następstwie przeprowadzonych przez organy ścigania czynności ustalono, że milicjant Piskorz: „mylnie zrobił meldunek uważając ob. Błaszek Jerzego jako b. policjanta granatowego Błażej Jerzego wzgl. Józefa”" ${ }^{11}$.

${ }^{24}$ IPN Kr 502/3496, Pismo Posterunku Gminnego M.O. w Ruszczy do Komendy Powiatowej Milicji Obyw. Referat Śledczy w Krakowie, Ruszcza, 25.01.1948, k. 45.

${ }^{25}$ IPN Kr 502/3496, Pismo Komisji Rehabilitacyjnej do Obywatela Prokuratora Sądu Okręgowego w Krakowie, Warszawa, 11.06.1948, k. 50.

${ }^{26}$ IPN Kr 502/3496, Pismo Prokuratury Sądu Okręgowego w Krakowie do Posterunku Milicji Obywatelskiej w Ruszczy, Kraków, 2.06.1948, k. 54.

${ }^{27}$ IPN Kr 502/3496, Pismo Posterunku Gminnego M.O. w Ruszczy do obyw. Prokuratora Sądu Okręgowego w Krakowie, Ruszcza, 17.06.1948, k. 53.

${ }^{28}$ IPN Kr 502/3496, Pismo Prokuratury Sądu Okręgowego w Krakowie do Wojewódzkiej Komendy Milicji Obywatelskiej w Krakowie, Kraków, 21.06.1948, k. 71.

${ }^{29}$ IPN Kr 502/3496, Meldunek do Kierownika III-go Kom. M.O. w Wałbrzychu, Wałbrzych, 8.02.1949, k. 73; IPN Kr 502/3496, Pismo Komendy M.O. na miasto Wałbrzych do Komendy Powiatowej M.O. w Krakowie, Wałbrzych, 5.03.1949, k. 74.

${ }^{30}$ IPN Kr 502/3496, Pismo Komendy M.O. na miasto Wałbrzych do Komendy Powiatowej M.O. w Krakowie, Wałbrzych, 5.03.1949, k. 74 .

${ }^{31}$ IPN Kr 502/3496, Wojewódzka Komenda Milicji Obywatelskiej w Krakowie do Komendy Miasta M.O. w Wałbrzychu, Kraków, 23.07.1949, k. 21; IPN Kr 502/3496, Komenda Milicji Obywatelskiej 
Sprawa o kolejnych sygnaturach:

IV Ko 46/54, IV Sb 52/53, IV K 32/54, II K 471/54

Sprawa działalności Jana Błażeja podczas okupacji niemieckiej stała się przedmiotem kolejnego postępowania prokuratorskiego w 1953 r. Poszukiwany został ujęty w sierpniu na Górnym Śląsku. Naczelnik Wydziału IV, wiceprokurator wojewódzki w Opolu E. Wojnar, z uwagi na właściwość miejscową, przesłał akta sprawy do Prokuratury Wojewódzkiej w Krakowie. Posiadała ona sygnaturę IV Ko 46/54.

Prokurator w Opolu nie zastosował wobec Błażeja środków zapobiegaw$\mathrm{Czych}^{33}$, dlatego wiceprokurator Marian Orzeł z Prokuratury Wojewódzkiej w Krakowie 7 sierpnia 1953 r., w ramach postępowania o sygnaturze akt IV Sb 52/53, wydał postanowienie o tymczasowym aresztowaniu. W uzasadnieniu stwierdzono, że Błażej Jan był podejrzany o przestępstwo $\mathrm{z}$ art. 1 pkt. 1 dekretu Z 31 sierpnia 1944 r. popełnione w następujący sposób: „w latach 1941-1944 w Ruszczy, pow. Kraków, idąc na rękę władzy państwa hitlerowskiego jako funkcjonariusz policji granatowej brał udział w zabójstwach osób narodowości żydowskiej"34. Zastosowanie środka zapobiegawczego było uzasadnione przepisem art. $152 \$ 1$ lit. a k.p.k., ponieważ w tych sprawach areszt był obligatoryjny $^{35}$. Na postanowienie przysługiwało zażalenie do Generalnej Prokuratury w Warszawie ${ }^{36}$. Kolejną czynnością było wydanie 14 sierpnia postanowienia

Województwa Krakowskiego Wydział Służby Śledczej do Prokuratury Sądu Apelacyjnego w Krakowie, Kraków, 29.03.1949, k. 93; IPN Kr 502/3496, Relacja z przeprowadzonych czynności służbowych w związku z poleceniem Prok. Sądu Apelacyjnego w Krakowie do akt sprawy x. Ds. 304/47 z dnia 24.03.1949, Wałbrzych, 26.03.1949, k. 94.

${ }^{32}$ ANK 29/747/IV K 32/54, t. 1, Pismo Prokuratury Wojewódzkiej w Opolu do Ob. Prokuratora Wojewódzkiego w Krakowie, Opole, 1.08.1953, k. 13.

${ }_{33}$ ANK 29/747/IV K 32/54, t. 1, Pismo Prokuratury Wojewódzkiej w Krakowie do Wojewódzkiego Urzędu Bezpieczeństwa Publicznego Wydział Śledczy, Kraków, 7.08.1953, k. 19-20.

${ }^{34}$ ANK 29/747/Iv K 32/54, t. 1, Postanowienie o tymczasowym aresztowaniu, Kraków, 7.08.1953, k. 15 .

35 Art. 152. \$1. Tymczasowe aresztowanie stosuje się: a) w sprawach określonych w art. $17 \$ 1$ pkt 1), 3), 4) i 5). Punkt 3 dotyczył zbrodni określonych w dekrecie $z$ dnia 31 sierpnia 1944 r. o wymiarze kary dla faszystowsko-hitlerowskich zbrodniarzy winnych zabójstw i znęcania się nad ludnością cywilną i jeńcami oraz dla zdrajców Narodu Polskiego.

${ }^{36}$ ANK 29/747/IV K 32/54, t. 1, Postanowienie o tymczasowym aresztowaniu, Kraków, 7.08.1953, k. 16. 
o przeprowadzeniu rewizji u podejrzanego ${ }^{37}$. Błażej został aresztowany 17 sierpnia 1953 r. przez wU BP w Opolu ${ }^{38}$.

Po rozpatrzeniu materiałów dochodzenia porucznik Jan Gil 18 sierpnia wydał oficjalne postanowienie o wszczęciu śledztwa wobec Jana Błażeja ${ }^{39}$. Tego samego dnia przetransportowano go do Wydziału Śledczego wUBP w Krakowie $^{40}$, gdzie odbyło się jego pierwsze przesłuchanie przez oficera śledczego ${ }^{41}$. Podejrzany próbował ukryć przed śledczym informacje o swojej pracy w granatowej policji. Opowiadając swój życiory,s pominął lata służby, twierdząc, że okres ten spędził, pracując jako robotnik fizyczny w gospodarstwie leśnym w Skolem ${ }^{42}$. Jednakże podczas kolejnego przesłuchania, również datowanego na 18 sierpnia, Błażej opowiedział o swojej pracy w granatowej policjił ${ }^{43}$.

W następnych miesiącach odbyły się kolejne przesłuchania podejrzanego; ich treść dotyczyła udziału policjantów granatowych z posterunku w Ruszczy w akcjach antyżydowskich. Ponieważ prowadzone śledztwo wymagało przesłuchania całego szeregu świadków ${ }^{44}$, prokurator trzykrotnie przedłużał areszt

37 ANK 29/747/IV K 32/54, t. 1, Postanowienie o zarządzeniu rewizji, Opole, 14.08.1953, k. 21. Rewizję domową w Głubczycach przeprowadził 17 sierpnia 1953 r. Zalewski Kazimierz. ANK 29/747/Iv K 32/54, t. 1, Protokół rewizji, Opole, 17.08.1953, k. 23. Rewizję osobistą przeprowadził Jan Barański funkcjonariusz wU BP w Krakowie. ANK 29/747/Iv K 32/54, t. 1, Protokół rewizji, Kraków, 17.08.1953, k. 25 .

${ }^{38}$ ANK 29/747/IV K 32/54, t. 1, Pismo do Prokuratora Wojewódzkiego Wydział IV-ty Karny, Kraków, 19.08.1953, k. 33.

${ }^{39}$ ANK 29/747/IV K 32/54, t. 1, Postanowienie o wszczęciu śledztwa, Kraków, 18.08.1953, k. 31-32.

${ }^{40}$ ANK 29/747/IV K 32/54, t. 1, Pismo do Prokuratora Wojewódzkiego Wydział IV-ty Karny, Kraków, 19.08.1953, k. 33.

${ }^{41}$ ANK 29/747/IV K 32/54, t. 1, Protokół przesłuchania podejrzanego, Kraków, 18.08.1953, k. 35.

42 ANK 29/747/IV K 32/54, t. 1, Protokół przesłuchania podejrzanego, Kraków, 18.08.1953, k. 37.

${ }^{43}$ „[...] Po napaści Niemiec hitlerowskich na Związek Radziecki i zajęciu tych terenów przez wojska niemieckie - na zarządzenie władz niemieckich zarejestrowałem się w Urzędzie Zatrudnienia, tzw. [Arbeitsamt] w Skale, jako b. funkcjonariusz Polskiej Policji Państwowej. Po zarejestrowaniu się w Urzędzie Zatrudnienia, w niedługim czasie otrzymałem wezwanie wstawienia się do Komendy Policji Granatowej w Krakowie. Zgodnie z wezwaniem, w miesiącu wrześniu lub październiku 1941 r. zgłosiłem się do biura policji w Krakowie, gdzie otrzymałem skierowanie do służby w policji granatowej na posterunek w Ruszczy pow. Kraków. Na posterunku policji granatowej w Ruszczy pełniłem służbę - jako starszy posterunkowy - do jesieni 1943 r., tj. do chwili zwolnienia się na własną prośbę z powodu choroby. Po zwolnieniu z policji wyjechałem spowrotem do Skalego". ANK 29/747/IV K 32/54, t. 1, Protokół przesłuchania podejrzanego, Kraków, 18.08.1953, k. 39-40.

${ }^{44} \mathrm{~W}$ aktach sprawy znajduje się ponad 6o protokołów przesłuchań świadków. 
tymczasowy zastosowany wobec Jana Błażeja ${ }^{45}$. Z materiałów pozostałych po postępowaniu przygotowawczym wynikało, że przeprowadzono siedem konfrontacji świadków z podejrzanym.

Postępowanie przygotowawcze umożliwiło postawienie zarzutów kolejnym osobom. Podejrzanymi o popełnienie przestępstw z dekretu sierpniowego, poza Błażejem, byli trzej inni policjanci granatowi pełniący podczas okupacji służbę na posterunku w Ruszczy: Guzek Ludwik ${ }^{46}$, Głuszek Franciszek ${ }^{47}$ i Kosteczko Hipolit ${ }^{48}$. W styczniu 1954 r. zebrane materiały śledcze w sprawie Fran-

${ }_{45}$ Za pierwszym razem areszt przedłużono do 7 grudnia $1953 \mathrm{r}$. ANK 29/747/IV K 32/54, t. 1, Wniosek, Kraków, 2.11.1953, k. 123; ANK 29/747/IV K 32/54, t. 1, Postanowienie o przedłużeniu aresztu tymczasowego, Kraków, 4.11.1953, k. 125. Dnia 3 grudnia 1953 r. kolejnym postanowieniem prokurator przedłużył areszt do 17 stycznia 1954 r. ANK 29/747/IV K 32/54, t. 1, Postanowienie o przedłużeniu aresztu tymczasowego, Kraków, 3.12.1953, k. 131. Postanowieniem z 13 stycznia przedłużono areszt tymczasowy do 17 lutego 1954 r. ANK 29/747/IV K 32/54, t. 1, Postanowienie o przedłużeniu aresztu tymczasowego, Kraków, 13.01.1954, k. 139.

${ }^{46}$ Guzek Ludwik, ur. 11 maja 1910 r. w Staromieściu (woj. Rzeszowskie), im. rodziców Jan i Katarzyna. Dnia 18 grudnia 1953 r. śledczy w и в P w Zielonej Górze wydał postanowienie o zarządzeniu rewizji domowej-osobistej u Ludwika Guzka. ANK 29/747/IV K 32/54, t. 1, Postanowienie o zarządzeniu rewizji, Zielona Góra, 18.12.1953, k. 175. Rewizję domową i osobistą przeprowadzono (st. sierż. Cebo Alfred funkcjonariusz wUBP w Zielonej Górze) 18 grudnia 1953 r. ANK 29/747/IV K 32/54, t. 1, Protokół rewizji, Żagań, 18.12.1953, k. 177-178. ANK 29/747/IV K 32/54, t. 1, Protokół rewizji, Żagań, 18.12.1953, k. 179. Pierwsze protokołowane przesłuchanie podejrzanego odbyło się 21 grudnia 1953 r. w Krakowie. ANK 29/747/IV K 32/54, t. 1, Protokół przesłuchania podejrzanego, Kraków, 21.12.1953, k. 183. Oficer śledczy wU BP w Krakowie Stanisław Tomasik wniósł o zastosowanie wobec Ludwika Guzka, aresztowanego 19 grudnia 1953 r., środka zapobiegawczego - aresztu tymczasowego z osadzeniem w więzieniu Montelupich w Krakowie. ANK 29/747/IV K 32/54, t. 1, Do Prokuratora Wojewódzkiego, Kraków, 21.12.1953, k. 189. Tego samego dnia wiceprokurator Marian Orzeł postanowił o tymczasowym aresztowaniu (do dnia 19 lutego 1954 r.). ANK 29/747/ IV K 32/54, t. 1, Postanowienie o tymczasowym aresztowaniu, Kraków, 21.12.1953, k. 191-192.

47 Głuszek Franciszek, ur. 8 stycznia 1898 r. w Stryszawie (pow. Żywiec), syn Szymona i Wiktorii z d. Kachel. Został aresztowany 9 sierpnia 1955 r. ANK 29/747/IV K 228/57, t. 1, Akt oskarżenia przeciwko Franciszkowi Głuszkowi i Hipolitowi Kosteczko, [b.m. b.d.], k. 176. Został skazany na karę łączną pięciu lat i sześciu miesięcy więzienia. Sąd Wojewódzki rozpoznał jego sprawę 2 grudnia 1955, 4 i 5 stycznia 1956 r. ANK 29/747/IV K 228/57, t. 2, Wyrok Sądu Wojewódzkiego w Krakowie, Kraków, 9.01.1956, k. 321v. Sąd Najwyższy umorzył jego postępowanie na mocy ustawy o amnestii. ANK 29/747/IV K 228/57, t. 2, Wyrok Sądu Najwyższego w Warszawie, Warszawa, 30.05.1956, k. 343-344.

${ }^{48}$ Hipolit Kosteczko, ur. 26 sierpnia 1911 r. w Siewierzu (k/Zawiercia), syn Tomasza i Stanisławy z d. Pieczara. Został aresztowany 14 czerwca 1955 r. ANK 29/747/IV K 228/57, t. 1, Akt oskarżenia przeciwko Franciszkowi Głuszkowi i Hipolitowi Kosteczko [b.m. b.d.], k. 177. Dnia 9 stycznia 1956 r. został skazany przez Sąd Wojewódzki w Krakowie na karę łączną dożywotniego więzienia oraz utraty praw publicznych i obywatelskich praw honorowych na zawsze. Sąd rozpoznał jego sprawę 
ciszka Głuszka i Hipolita Kosteczki, na mocy postanowienia oficera śledczego por. Stanisława Tomasika, zostały wyłączone do odrębnego postępowania ${ }^{49}$.

Oficer śledczy wUBP postanowił zakończyć śledztwo w sprawie Jana Błażeja i Ludwika Guzka aktem oskarżenia ${ }^{50}$. Podejrzanym wyjaśniono, jakie przestępstwa im zarzucano, i zapoznano ich $\mathrm{z}$ treścią zebranych dowodów ${ }^{51}$. Jan Błażej po raz ostatni w ramach tego śledztwa został przesłuchany 15 lutego $1954 \mathrm{r}^{52} \mathrm{~W}$ lutym zamknięto śledztwo ${ }^{53}$. Akt oskarżenia został sporządzony przez por. Stanisława Tomasika, oficera śledczego wU B P w Krakowie, i zatwierdzony przez szefa wUB P 17 lutego $1954 \mathrm{r}^{54}$ Tego samego dnia referendarz śledczy zaaprobował akt oskarżenia. Można przypuszczać, że jego podpis był jedynie formalnością̧5 . W ukształtowanym przez komunistów wymiarze sprawiedliwości rola prokuratorów miała sprowadzać się do zatwierdzania aktów oskarżenia, a sędziów - do orzekania kar zgodnie z sugestiami organów prowadzących śledztwo ${ }^{56}$.

2 grudnia 1955 r., 4 i 5 stycznia 1956 r. ANK 29/747/IV K 228/57, t. 2, Wyrok Sądu Wojewódzkiego w Krakowie, Kraków, 9.01.1956, k. 320-330. Sąd Najwyższy uchylił karę i przekazał jego sprawę do ponownego rozpatrzenia. ANK 29/747/IV K 228/57, t. 2, Wyrok Sądu Najwyższego w Warszawie, Warszawa, 30.05.1956, k. 343-347. Po wznowieniu postępowania sądowego Sąd Wojewódzki skazał Kosteczkę na 12 lat więzienia i utratę praw publicznych i honorowych na 10 lat. Sprawa oskarżonego była rozpatrywana 18 października, 5 i 22 listopada 1957 r. ANK 29/747/IV K 228/57, t. 3, Wyrok Sądu Wojewódzkiego w Krakowie, Kraków, 25.11.1957, k. 738-740v. Sąd Najwyższy utrzymał ten wyrok w mocy. ANK 29/747/IV K 228/57, t. 3, Wyrok Sądu Najwyższego w Warszawie, Warszawa, 19.02.1958, k. 745-747.

49 ANK 29/747/IV K 32/54, t. 2, Postanowienie o wyłączeniu materiałów do odrębnego prowadzenia, Kraków, 23.01.1954, k. 707.

50 ANK 29/747/IV K 32/54, t. 2, Postanowienie o wyłączeniu materiałów do odrębnego prowadzenia, Kraków, 23.01.1954, k. 707.

${ }^{51}$ ANK 29/747/IV K 32/54, t. 2, Protokół zaznajomienia podejrzanego z materiałami śledztwa, Kraków [b.d.], k. 723.

${ }^{52}$ ANK 29/747/IV K 32/54, t. 2, Protokół końcowego przesłuchania podejrzanego, Kraków, 13.02.1954, k. 681-694; ANK 29/747/IV K 32/54, t. 2, Protokół końcowego przesłuchania podejrzanego, Kraków, 15.02.1954, k. 695-703.

53 ANK 29/747/IV K 32/54, t. 2, Postanowienie o zamknięciu śledztwa, Kraków [02.1954], k. 727.

54 ANK 29/747/IV K 32/54, t. 2, Akt oskarżenia przeciwko: Błażej Janowi i Guzkowi Ludwikowi, Kraków, 17.02.1954, k. 731-753.

55 Podpisany referendarz śledczy St. Bartkowski. ANK 29/747/IV K 32/54, t. 2, Postanowienie Prokuratury Wojewódzkiej w Krakowie, Kraków, 17.02.1954, k. 872.

${ }^{56}$ J. Borowiec, Zbrodnie popetnione na Żydach przez oddział Gwardii Ludowej „Iskra” w świetle dokumentów sądowych, [w:] Z dziejów stosunków polsko-żydowskich w xx wieku, red. E. Czop, E. Rączy, Rzeszów 2009, s. 75; A. Lityński, Na drodze ku nowej procedurze karnej: o postępowaniu 
Akt oskarżenia wniesiony do Sądu Wojewódzkiego w Krakowie zawierał wszystkie obligatoryjne elementy (art. 247 k.p.k.). Sporządzający akt oskarżenia określił tożsamość oskarżonego, podając jego imię i nazwisko oraz inne dane osobowe, takie jak data urodzenia, zawód, stan cywilny i wykształcenie. Dość dokładnie opisywano czyn popełniony przez oskarżonego, wskazywano czas i miejsce jego dokonania.

$\mathrm{W}$ analizowanej sprawie niejednokrotnie nie podawano dokładnej daty dziennej popełnionego czynu, poprzestawano na miesiącu i roku. Przy formułowaniu aktu oskarżenia dokonano kwalifikacji prawnej zachowania sprawcy. W tym przypadku czyny opisane pod pkt. 1 od lit. a-h stanowiły przestępstwo $\mathrm{z}$ art. 1 pkt. $1^{57}$, zaś czyny pod pkt. II litera $\mathrm{a}-\mathrm{b}-\mathrm{z}$ art. $3^{58}$ dekretu $\mathrm{z}$ dnia 31 sierpnia 1944 r. Akt oskarżenia zawierał uzasadnienie $z$ listą świadków i innych dowodów. Wskazywano również sąd właściwy do rozpoznania sprawy. Na podstawie art. $17 \$ 1$ pkt. 3 i art. $20 \$ 1$ k.p.k. sprawa podlegała rozpatrzeniu przez Sąd Wojewódzki w Krakowie.

Sprawa Jana Błażeja i Ludwika Guzka toczyła się przed Sądem Wojewódzkim pod sygnaturą IV K 32/54. Termin rozprawy został wyznaczony na 9, 10 i 11 marca 1954 r. ${ }^{59} \mathrm{~W}$ tym czasie Błażej przebywał w więzieniu w Krakowie przy ul. Montelupich ${ }^{60}$. Jego obrońcą był adwokat z wyboru Daniel Hrehorowicz, któremu pełnomocnictwa udzieliła żona oskarżonego ${ }^{61}$. Przed rozprawą adwokat wniósł o wezwanie na rozprawę świadków, którzy mieli wyjaśnić „okoliczności: jak się zachowywał i jak pracował oskarżony w Polsce wyzwolonej”62. Linia obrony, powołując się na orzecznictwo Sądu Najwyższego ${ }^{63}$, polegała

przygotowawczym w latach 1943-1950, [w:] Przestępstwa sędziów i prokuratorów w Polsce lat 1944-1956, red. W. Kulesza, A. Rzepliński, Warszawa 2001, s. 51.

57 Branie udziału w dokonywaniu zabójstw osób spośród ludności cywilnej albo osób wojskowych lub jeńców wojennych.

${ }^{58}$ Wymuszanie świadczeń pod groźbą wywołania prześladowań albo działanie w inny sposób na szkodę osób poszukiwanych lub prześladowanych.

59 ANK 29/747/IV K 32/54, t. 2, Zarządzenie o wyznaczeniu rozprawy głównej, [b.m.] 23.02.1954, k. 759 .

${ }^{60}$ ANK 29/747/IV K 32/54, t. 2, Prokuratura Wojewódzka w Krakowie do Sądu Wojewódzkiego Wydział IV w Krakowie, Kraków, 17.02.1954, k. 757.

${ }_{61}$ ANK 29/747/IV K 32/54, t. 2, Pełnomocnictwo, Głubczyce, 25.02.1954, k. 769.

${ }^{62}$ ANK 29/747/IV K 32/54, t. 2, Wniosek o dopuszczenie dowodu ze świadków i wezwanie ich na rozprawę w dniu 11-ym marca 1954 r. do Sądu Wojewódzkiego Wydział Iv Karny w Krakowie, Kraków, 5.03.1954, k. 861-862.

${ }^{63}$ „Z uwagi na judykaturę Sądu Najwyższego (vide postanowienie 7 Sędziów Izby Karnej S.N. z 22.8.51 Sygn.II.K.128/50 wg „Państwo i Prawo” zesz. $10 \mathrm{z} \mathrm{V/51)} \mathrm{stojącą} \mathrm{na} \mathrm{stanowisku,} \mathrm{iż} \mathrm{szczera}$ 
na przedstawieniu pozytywnej sylwetki oskarżonego w nowej rzeczywistości społeczno-politycznej ${ }^{64}$. Sąd zgodził się na dopuszczenie dwóch świadków obrony $^{65}$. Według zgromadzonego materiału Błażej nie był notowany ${ }^{66}$.

Ostatecznie przed Sądem Wojewódzkim w Krakowie rozprawy przeprowadzono 9, 10, 11 i 29 marca 1954 r. Ogłoszenie wyroku odbyło się 31 marca 1954 r. $^{67}$ Sąd wymierzył oskarżonemu Błażejowi karę dożywotniego więzienia ${ }^{68}$ $\mathrm{z}$ równoczesną utratą praw publicznych i obywatelskich praw honorowych. Współoskarżony Ludwik Guzek został skazany na karę 15 lat więzienia ${ }^{69}$. Sąd Najwyższy, na posiedzeniu jawnym 2 czerwca 1954 r., rozpoznał rewizję złożoną przez oskarżonych (sygnatura akt sprawy II K 471/54), która zarzucała rażącą surowość kar, i utrzymał w mocy zaskarżony wyrok ${ }^{70}$.

\section{Akta postępowań karnych jako źródło do stosunków polsko-żydowskich}

Badanie stosunków polsko-żydowskich z czasów okupacji nie należy do łatwych. Materiały źródłowe, z których można korzystać, są niekompletne, badacze opierają się na bardzo zróżnicowanej i niedającej jednoznacznego obrazu bazie źródłowej. Istotnym czynnikiem jest również ogromny

pozytywna praca w Polsce Ludowej po wyzwoleniu uznaną być powinna za szczególną okoliczność łagodzącą uzasadniającą zastosowanie nadzwyczajnego złagodzenia kary”. ANK 29/747/IV K 32/54, t. 2, Wniosek o dopuszczenie dowodu ze świadków i wezwanie ich na rozprawę w dniu 11-ym marca 1954 r. do Sądu Wojewódzkiego Wydział Iv Karny w Krakowie, Kraków, 5.03.1954, k. 862.

${ }^{64}$ ANK 29/747/IV K 32/54, t. 2, Wniosek o dopuszczenie dowodu ze świadków i wezwanie ich na rozprawę w dniu 11-ym marca 1954 r. do Sądu Wojewódzkiego Wydział Iv Karny w Krakowie, Kraków, 5.03.1954, k. 862.

${ }_{5}$ ANK 29/747/IV K 32/54, t. 2, Postanowienie Sądu Wojewódzkiego w Krakowie, Kraków, 6.03.195[4], k. 863 .

${ }^{66}$ ANK 29/747/IV K 32/54, t. 2, Zapytanie o karalność, [b.m.] 21.08.1953, k. 709; ANK 29/747/IV K 32/54, Zapytanie o karalność, [b.m.] 22.08.1953, k. 710.

${ }^{67}$ ANK 29/747/IV K 32/54, t. 2, Protokół ogłoszenia wyroku, Kraków, 31.03.1954, k. 997.

${ }^{68}$ Jan Błażej był oskarżony m.in. o przestępstwa $\mathrm{z}$ art. 1 pkt 1 zagrożone sankcją - karą śmierci. Sąd Wojewódzki zastosował nadzwyczajne złagodzenie kary na podstawie art. $5 \$ 1$ i 2 dekretu sierpniowego. Upoważnienie do nadzwyczajnego złagodzenia kary ze względu na osobę sprawcy lub okoliczności czynu, zostało wprowadzone nowelą grudniową i osłabiło pierwotną surowość dekretu sierpniowego. A. Pasek, Przestępstwa okupacyjne..., dz. cyt., s. 162.

${ }^{69}$ ANK 29/747/IV K 32/54, t. 2, Sentencja Wyroku, Kraków, 31.03.1954, k. 999-1012.

${ }^{70}$ ANK 29/747/Iv K 32/54, t. 2, Wyrok Sądu Najwyższego w Warszawie, Warszawa, 2.06.1954, k. 1061-1064. 
stopień rozproszenia materiałów źródłowych w wielu instytucjach i wielu krajach świata ${ }^{71}$.

Co można ustalić na podstawie akt postępowań karnych? Z dotychczas przeprowadzonych badań wiemy, że część spraw prowadzonych na podstawie dekretu sierpniowego, które trafiały na wokandę, nie zawsze była rzetelnie przygotowana przez prokuraturę lub inne organy ścigania. Śledztwa prowadzono powierzchownie, co przekładało się na słabość materiału dowodowego, którym dysponował sąd w stosunku do oskarżonych. To dlatego część z nich bywała uniewinniana lub sprawy umarzano ${ }^{72}$. Niestety nie wiemy, w jakim stopniu opisane zjawisko było powszechne.

Z drugiej strony prowadzący śledztwo funkcjonariusze UB mogli starać się dostosować materiał dowodowy do treści stawianych zarzutów, nie uwzględniając tych wyjaśnień i zeznań świadków, które nie odpowiadały konstrukcji oskarżenia. Często wymuszali przyznanie się do niepopełnionego przestępstwa przez stosowanie niedozwolonych metod śledczych ${ }^{73}$. W badanych aktach nie zachowały się informacje, które mogłyby świadczyć o stosowaniu podczas postępowania przygotowawczego przemocy wobec podejrzanego, jednakże nie można tego z całą pewnością wykluczyć. W toku przeprowadzonej analizy akt nie udało się również ustalić, czy na sędziów orzekających w tej sprawie wywierano nieformalne naciski. Nie znaleziono dokumentów, które mogłyby potwierdzić, że wyrok skazujący był inspirowany przez funkcjonariuszy UB.

${ }^{71}$ Na temat podstawowych zespołów archiwalnych i źródeł wykorzystywanych do badań nad stosunkami polsko-żydowskimi podczas niemieckiej okupacji zob. m.in.: A. Skibińska, Źródła do badań nad zagłada Żydów na okupowanych ziemiach polskich. Przewodnik archiwalnobibliograficzny, Warszawa 2007; A. Krochmal, Pomoc Żydom w czasie II wojny światowej w świetle polskich i niemieckich źródeł archiwalnych, [w:] Z dziejów stosunków polsko-żydowskich w xx wieku, red. E. Czop, E. Rączy, Rzeszów 2009, s. 38-55; Z. Schnepf-Kołacz, Pomoc Polaków dla Żydów na wsi w czasie okupacji niemieckiej. Próba opisu na przykładzie Sprawiedliwych wśród Narodów Świata, [w:] Zarys krajobrazu..., dz. cyt., s. 195-197; J. Leociak, Literatura dokumentu osobistego jako źródła do badań nad zagładą Żydów. Rekonesans metodologiczny, „Zagłada Żydów. Studia i materiały" (2005) nr 1, s. 13-31.

72 E. Rączy, Negatywne postawy mieszkańców powiatu przemyskiego podczas niemieckiej okupacji w świetle powojennych procesów, [w:] Miasta i ludzie. Sacrum i profanum. Studia z dziejów społecznych i gospodarczych dedykowane Profesorowi Jerzemu Motylewiczowi, red. P. Grata, B. Lorens, Rzeszów 2013, s. 265.

73 R. Śmietanka-Kruszelnicki, Protokół przesłuchania jako źródło historyczne, „Pamięć i Sprawiedliwość” 2 (2003) nr 1(3), s. 199-207; J. Borowiec, Metody śledcze stosowane podczas przestuchań przez pracowników urzędów bezpieczeństwa publicznego, „Studia Rzeszowskie” 2 (1995), S. $45-58$. 
Opierając się na dokumentacji sądowej, należy pamiętać, że wymiar sprawiedliwości był uwikłany w politykę, a jego obiektywizm jest podawany w wątpliwość. Rozprawa sądowa miała miejsce w 1954 r., a więc kiedy procesy sierpniowe były raczej rzadkością. Sprawa ta nie miała charakteru procesu pokazowego lub politycznego, jednakże w uzasadnieniu wyroku pojawiły się kwestie polityczne ${ }^{74}$.

Analizowane akta zawierają informacje o sprawcach, którzy dokonali czynów wpisujących się w niemieckie prześladowania ludności żydowskiej. Na podstawie materiałów ze śledztwa i postępowania dowodowego możemy podjąć próbę przedstawienia sylwetek oskarżonych policjantów granatowych, dowiedzieć się, kim byli, ustalić posterunek, z którego pochodzili, oraz jego obsadę ${ }^{75}$.

Według ustaleń dokonanych w toku postępowań karnych Jan Błażej urodził się 22 marca 1899 r. w Hołowiecku ${ }^{76}$. Po ukończeniu siedmiu klas szkoły powszechnej w Skolem, odbył praktykę leśną. W 1916 r. został powołany do wojska w armii austriackiej. Podczas I wojny światowej brał udział w walkach na froncie włoskim. Od 1918 do 1921 r. służył w Wojsku Polskim. Od 1922 do września 1939 r. pełnił służbę w policji państwowej. Początkowo pracował w Powiatowej Komendzie Policji Powiatowej w Stanisławowie, a od 1930 r. w Powiatowej Komendzie Policji w Nagórnej. W 1941 r. zgłosił się

${ }^{74}$ W uzasadnieniu wyroku z 31 marca 1954 r.: „Sąd miał również na uwadze, że obydwaj oskarżeni są pochodzenia proletariackiego, że więc nie byli świadomymi wyznawcami ideologii faszyzmu, jakkolwiek swemi czynami szli im na rękę, że natomiast psychika ich kształtowała się przez długie lata pod fatalnymi wpływami ustroju wyzysku i nędzy, co doprowadziło ich między innymi w szeregi policji granatowej, a w dalszym ciągu na drogę przestępstwa”. ANK 29/747/Iv K 32/54, t. 2, Sentencja Wyroku, Kraków, 31.03.1954, k. 1012. W innym miejscu sąd stwierdzał, że: „jeszcze jeden aspekt czynów powyższych stanowi swego rodzaju moralne poparcie udzielone im przez cieszący się wówczas autorytetem dwór, co wyraża się w libacji urządzonej przez właściciela dworu w Kościelnikach dla policjantów granatowych po zastrzeleniu rodziny Zacięskich”. ANK 29/747/ IV K 32/54, t. 2, Sentencja Wyroku, Kraków, 31.03.1954, k. 1010. Na temat stosunku ziemiaństwa do ludności żydowskiej na obszarze województwa krakowskiego podczas okupacji niemieckiej zob.: M. Chorązki, Ziemianie wobec wojny. Postawy właścicieli ziemskich województwa krakowskiego w latach 1939-1945, Kraków 2010, s. 177-184.

75 ANK 29/747/IV K 32/54, t. 2, Sentencja wyroku, Kraków, 31.03.1954, k. 999-1012.

${ }^{76}$ W swoich wspomnieniach Bernard Traub Trawiński pisał: „wspominałem już, że dwóch policjantów, pochodzenia ukraińskiego, węszyło całymi dniami w poszukiwaniu mego rodzeństwa i innych ukrywających się Żydów”. B. Trawiński, Przebłyski czarnej nocy..., dz. cyt., s. 106. Jednym z tych policjantów był Jan Błażej. W dokumentacji dotyczącej jego danych osobowych zapisano: „narodowość polska” i „obywatelstwo polskie”. ANK 29/747/IV K 32/54, t. 1, Protokół przesłuchania podejrzanego, Kraków, 18.08.1953, k. 35-38. 
do policji granatowej i został skierowany do posterunku w Ruszczy, gdzie pełnił służbę do jesieni 1943 r. Z zachowanej dokumentacji wiemy, że na tej placówce pracowali również komendant Głuszek oraz policjanci: Guzek, Goryczko, Kosteczko i Marusiewicz. Jesienią 1943 r. Jan Błażej został zwolniony z policji $\mathrm{i}$,wyjechał na tereny wschodnie, gdzie pracował jako gajowy, aż do odwrotu władz okupacyjnych". W styczniu 1945 r. powrócił do miasta Skole, następnie wyjechał do Tomaszowa Lubelskiego, gdzie do 1946 r. pracował w miejscowym tartaku. Następnie przeniósł się do Opola, a później do Głubczyc i pracował w Państwowym Zarządzie Drogowym. Od 1951 r. pracował w Powiatowej Radzie Narodowej jako referent skarg i zażaleń ${ }^{77}$.

Akt oskarżenia skierowany wobec Jana Błażeja dotyczył przestępstw popełnionych wobec ludności żydowskiej i polskiej ${ }^{78}$. W lecie 1942 r. policja granatowa została wykorzystana przez Niemców do wsparcia akcji eksterminacyjnej ludności żydowskiej w Wieliczce ${ }^{79}$. Według ustaleń dokonanych $\mathrm{w}$ śledztwie i postępowaniu dowodowym egzekucje były przeprowadzane przez samych Niemców na cmentarzu żydowskim. Błażej brał udział w patrolowaniu ulic oraz w eskortowaniu osób przeznaczonych na rozstrzelanie. Po kilku dniach, uzyskawszy zwolnienie od lekarza, powrócił na posterunek w Ruszczy ${ }^{80}$.

77 ANK 29/747/IV K 32/54, t. 1, Protokół przesłuchania podejrzanego, Kraków, 18.08.1953, k. 35 ANK 29/747/IV K 32/5438; ANK 29/747/IV K 32/54, t. 2, Charakterystyka, Kraków, 12.12.1953, k. 717-719.

${ }^{78}$ Czyny opisane pod pkt. 1 od lit. a) do h) stanowiły przestępstwo $\mathrm{z}$ art. 1 pkt. 1 zaś czyny pkt. II litera a-b - z art. 3 dekretu z dnia 31 sierpnia 1944 r. ANK 29/747/IV K 32/54, t. 2, Akt oskarżenia przeciwko: Błażej Janowi i Guzkowi Ludwikowi, Kraków, 17.02.1954, k. 731-753.

79 Prawdopodobnie chodzi o akcję likwidacji skupiska ludności żydowskiej w Wieliczce w sierpniu 1942 r. w ramach Aktion Reinhard. Dnia 26 sierpnia Wieliczka została otoczona przez niemieckie siły policyjne i policję granatową. Następnego dnia wymordowano chorych z żydowskiego szpitala i jego personel (w sumie 150 osób). 28 sierpnia nakazano całej ludności żydowskiej Wieliczki zebrać się na łąkach koło stacji kolejowej. Następnie poddano ludzi selekcji. Niezdolni do pracy lub do dalszej drogi zostali wywiezieni do Niepołomic i tam rozstrzelani. Młodzi mężczyźni zostali wywiezieni do obozów pracy, a pozostałą ludność deportowano do obozu zagłady w Bełżcu. Przez kilka kolejnych dni wyłapywano i mordowano żydowskich uciekinierów na ulicach lub na żydowskim cmentarzu. E. Rączy, Zagłada Żydów w dystrykcie krakowskim..., dz. cyt., s. $287-288$.

${ }^{80}$ ANK 29/747/IV K 32/54, t. 1, Protokół przesłuchania świadka K. Ż., Ruszcza, 6.07.1953, k. 261-264; ANK 29/747/IV K 32/54, t. 2, Protokół przesłuchania świadka S. M., Kraków, 11.12.1953, k. 589-592; ANK 29/747/IV K 32/54, t. 2, Protokół przesłuchania świadka J. P., Kraków, 10.12.1953, k. 593-597; ANK 29/747/IV K 32/54, t. 2, Sentencja Wyroku, Kraków, 31.03.1954, k. 1003. 
Policjant Błażej w styczniu 1943 r. uczestniczył w egzekucji rodziny Messingerów $^{81}$. W maju 1943 r. z komendantem posterunku Franciszkiem Głuszkiem i żandarmami niemieckimi ujął w domu Franciszka Kalisza ${ }^{82}$ w Branicach żydówkę Wajsmanową (Tonia Weisfeld/Weisman - zamordowana przez Niemców). Następnego dnia po egzekucji powrócił do domu Kaliszów, odnalazł i zastrzelił jej czteroletnie dziecko ${ }^{83}$. Latem 1943 r. wraz z policjantami Guzkiem i Kosteczką zastrzelili ukrywających się we dworze w Kościelnikach ${ }^{84}$ dwóch Żydów i dwie Żydówki (Zaciewscy, Zundlewicz i Wilczyńska) ${ }^{85}$. Ponadto Błażej

${ }^{81}$ „[... Następnie byłem naocznym świadkiem morderstwa rodziny Messingerów w Ruszczy, której dokonali policjanci z posterunku w Ruszczy, a to Błażej Jan, Kosteczko i Guzek. Komendantem tej egzekucji był Błażej Jan i on wydawał rozkazy strzelania do żydów oraz sam strzelał z karabinu lub pistoletu [...] Kosteczko i Guzek oddali strzały do Messingerów, natomiast Błażej Jan jak przypominam sobie z broni krótkiej pistoletu oddał strzał do żony Messingera i ich dziecka”. ANK 29/747/IV K 32/54, t. 1, Protokół przesłuchania świadka F. B., Kraków, [28].07.1953, k. 301-303. „Na przełomie grudnia 19[42] i stycznia 19[43] posterunkowy Kosteczko Hipolit, działając na własną rękę pod nieobecność komendanta Posterunku, ujął ukrywającą się w domu Franciszka Czajki w Kościelnikach rodzinę żydowską Messingerów, składającą się z męża, żony i syna 8-10-letniego, którą doprowadził do aresztu gminnego. Na drugi dzień posterunek policji w Ruszczy otrzymał z Komendy Powiatowej w Krakowie telefonicznie rozkaz zlikwidowania zastrzelonych [...]. W wykonaniu powyższego rozkazu Kosteczko, Błażej i nieustalonego nazwiska trzeci policjant, wzorem poprzedniej egzekucji, wyprowadzili rodzinę Messingerów na cmentarz, gdzie wspólnie zastrzelili ich, polecając następnie pogrzebanie w przygotowanym zawczasu dole”. ANK 29/747/IV K 32/54, t. 2, Sentencja Wyroku, Kraków, 31.03.1954, k. 1005.

${ }^{82}$ Franciszek Czajka, ur. 7 grudnia 1897 r., [Kraków], syn Franciszka i Rozalii.

${ }_{33}$ ANK 29/747/IV K 32/54, t. 1, Protokół przesłuchania świadka Anny Kalisz, Kraków, 8.07.1953, k. 333-336; ANK 29/747/Iv K 32/54, t. 1, Protokół przesłuchania świadka Antoniego Gawlika, Kraków, 2.10.1953, k. 383-387; ANK 29/747/IV K 32/54, t. 1, Protokół przesłuchania świadka Mieczysławy Kalisz, Kraków, 8.07.1953, k. 389-393; ANK 29/747/IV K 32/54, t. 1, Protokół przesłuchania świadka Józefy Matuszczyk, Kraków, 8.07.1953, k. 357-359; ANK 29/747/IV K 32/54, t. 1, Protokół przesłuchania świadka Franciszka Kalisza, Kraków, 9.10.1953, k. 403-406.

${ }^{84}$ ANK 29/747/IV K 32/54, t. 1, Protokół przesłuchania świadka Władysława Bąka, Kraków, 8.07.1953, k. 321-325.

${ }^{85}$ Sąd, opierając się na zeznaniach świadków, poczynił następujące ustalenia: „W dniu 13.5.1943 r. oskarżony Błażej i Guzek wraz z policjantem Kosteczką na polecenie komendanta Głuszka udali się do domu Wodzickiej w Kościelnikach celem ujęcia zamieszkałej tamże rodziny żydowskiej złożonej z małżeństwa Zacięskich, występujących pod nazwiskiem Zundlewicz, ich syna oraz krewnej czy znajomej Wilczyńskiej. Po zidentyfikowaniu tych osób jako narodowości żydowskiej policjanci wszyscy trzej zabrali je z dworu, udając się z nimi w kierunku Ruszczy. Po drodze osk. Błażej oddalił się od grupy, wracając w kierunku dworu, jak twierdzi, w celu otrzymania bliższych wyjaśnień o zatrzymanych. Z odległości kilkudziesięciu metrów usłyszał strzały, które skłoniły go do powrotu na miejsce. Tam zastał wszystkie osoby zatrzymane leżące 
ujął ukrywającą się w domu Władysława Bąka ${ }^{86}$ żydówkę Wiktorię Słowikową, która została następnie zastrzelona przez policjanta Guzka ${ }^{87}$. Latem lub jesienią 1942 [43] r. wraz z policjantami Guzkiem, Kosteczką i żandarmami niemieckimi brał udział w zamordowaniu [nieznanych z nazwiska] siedmiu Żydów ujętych na szosie Kraków-Brzesko ${ }^{88}$. Jesienią 1943 r. zastrzelił żydówkę Halinę Gorberg/Golberg w Wyciążu ${ }^{89}$. W skład drugiej kategorii czynów popełnionych przez Błażeja wchodziły działania skierowane wobec ludności polskiej ${ }^{90}$. Sąd

bez życia na drodze. Miał je zabić wedle wyjaśnień obu oskarżonych sam Kosteczko bez żadnego uprzedzenia o tym towarzyszących mu kolegów. Na miejsce wypadku zjechał komendant posterunku i wójt gminy Ruszcza. Sprowadzono ludzi do zakopania zwłok, zaś Kosteczko i Guzek podzielili się przy ofiarach znalezioną biżuterią". ANK 29/747/IV K 32/54, t. 2, Sentencja Wyroku, Kraków, 31.03.1954, k. 1006-1007.

${ }^{86}$ Władysław Bąk, ur. 19 lipca 1903 r. w Kościelnikach, syn Jana i [Józefy].

${ }^{87}$ ANK 29/747/IV K 32/54, t. 1, Protokół przesłuchania świadka Władysława Bąka, Kraków, 8.07.1953, k. 322-324; ANK 29/747/IV K 32/54, t. 2, Protokół rozprawy głównej przed Sądem Wojewódzkim w Krakowie Wydział ıv Karny [Zeznanie świadka Władysława Bąka], Kraków, 11.03.1954, k. 895-896.

${ }^{88}$ „Egzekucji dokonał pluton złożony w połowie z policjantów a w połowie z Niemców, przy czym w skład jego wchodzili obaj oskarżeni [...] po wspólnej salwie zaszła konieczność dobijania ofiar, czego dokonał jeden z Niemców z pistoletu automatycznego". ANK 29/747/IV K 32/54, t. 2, Sentencja Wyroku, Kraków, 31.03.1954, k. 1004. „W lecie 1942 r. lub 1943 r., daty dokładnej nie pamiętam, na szosie wiodącej z Krakowa do Proszowic zostali zatrzymani żydzi przez niemców [sic!]. Po zatrzymaniu zostali oni doprowadzeni do aresztu gminnego w Ruszczy. Do aresztu gminnego w Ruszczy zostali oni doprowadzeni przez policję granatową z posterunku Ruszcza. W czym brali udział znani mi policjanci Błażej Jan, Kosteczko, Głuszek lub Guzek i jeszcze jeden, którego w tej chwili nazwiska nie pamiętam. Żydów tych było siedmiu tj. trzech mężczyzn, trzy niewiasty i jedno dziecko w wieku od 10-13 lat. [...] żydów tych przywieziono do aresztu w Ruszczy w godzinach rannych i tego samego dnia w godzinach popołudniowych przed zachodem słońca zostali oni zastrzeleni. W rozstrzelaniu tych żydów brali udział - Błażej Jan, Kosteczko, Guzek i dwóch Niemców i jeden gestapowiec z posterunku w Ruszczy. Egzekucją kierował gestapowiec, jeśli chodzi, kto strzelał do Żydów, wyjaśniam, że strzelali wszyscy policjanci, a między innymi Błażej Jan. Zbrodni tej byłem naocznym świadkiem, gdyż z innymi kolegami, których nie pamiętam, staliśmy za murem cmentarza i przyglądaliśmy się, jak policjanci i niemcy wspólnie razem strzelają żydów”. ANK 29/747/IV K 32/54, t. 1, Protokół przesłuchania świadka F. B., Kraków, [28].07.1953, k. 301-303. „W roku 1943 na szosie koło Cła uchwycono 6 lub siedem osób narodowości żydowskiej, kto ich złapał, jadąc tą szosą, ja tego nie wiem”. ANK 29/747/IV K 32/54, t. 1, Protokół przesłuchania świadka R. T., Kraków, 7.07.1953.

${ }^{89}$ ANK 29/747/IV K 32/54, t. 2, Sentencja Wyroku, Kraków, 31.03.1954, k. 1007.

90 „a) w okresie 1942-43 r. daty bliżej nie ustalonej w Branicy pow. Kraków, wspólnie z innymi funkcjonariuszami policji polskiej, zatrzymał około 10 osób, które uchylały się od wyjazdu na przymusowe roboty do Niemiec. b) wiosną 1943 r. daty bliżej nie ustalonej w Kościelnikach 
Wojewódzki w Krakowie w uzasadnieniu wyroku uznał, że czyny popełnione wobec Polaków miały w tej sprawie znaczenie marginesowe ${ }^{91}$.

Analizując akta postępowań karnych, można podjąć próbę przedstawienia motywów popełnienia konkretnego czynu. Należy pamiętać, że jest to trudne, niekiedy nie udało się $\mathrm{w}$ trakcie przewodu sądowego ustalić rzeczywistych przyczyn działań oskarżonych ${ }^{92}$. W analizowanym przypadku na pierwszej rozprawie, która odbyła się 9 marca ${ }^{93}$, oskarżony Błażej usprawiedliwiał swoje działania w następujący sposób: „trzykrotnie chciałem się zwolnić, widząc, że robią $\mathrm{z}$ nas morderców, w pracy byłem opieszały, za co dostałem naganę. Gdybym się nie zgłosił do pracy w policji, wywieziono by mnie do Oświęcimia albo postawiono przed sąd wojskowy, gdzie groziła mi śmierć. Nigdy ochotniczo do żadnych akcji się nie zgłaszałem, lecz zawsze działałem na rozkaz"94. Podczas ostatniej rozprawy przed Sądem Wojewódzkim w Krakowie oskarżony wyjaśniał: „mieliśmy wyraźny rozkaz likwidować wszystkie napotkane osoby narodowości żydowskiej. My, chcąc oszczędzić Polaków, u których znaleziono Żydów, podawaliśmy w raportach, że ujęci byli na polach, nie podając, u kogo byli przechowywani. Gdybyśmy Żydów nie zabijali sami na miejscu, a dostawili ich do Niemców, spotkałby ich ten sam los, a przy tym wyszłoby na jaw, u kogo się ukrywali"95.

Usprawiedliwienia obu skazanych policjantów granatowych sprowadzały się ponadto do tłumaczenia, że czynów opisanych w akcie oskarżenia dopuścili się, działając na rozkaz, powoływali się na ogólne pisemne zarządzenie władz

pow. Kraków przeprowadził dwukrotnie rewizje w domu BARANA Stanisława w poszukiwaniu ukrywających się tam obywateli narodowości żydowskiej”. ANK 29/747/Iv K 32/54, t. 2, Akt oskarżenia przeciwko: Błażej Janowi i Guzkowi Ludwikowi, Kraków, 17.02.1954, k. 731-753.

${ }^{91}$ ANK 29/747/IV K 32/54, t. 2, Sentencja Wyroku, Kraków, 31.03.1954, k. 1011.

92 E. Rączy, Negatywne postawy..., dz. cyt., s. 267. Na temat motywacji sprawców zbrodni na Żydach na wsi kieleckiej w latach 1942-1944 zob. A. Skibińska, „Dostat 10 lat, ale za co?”. Analiza motywacji sprawców zbrodni na Żydach na wsi kieleckiej w latach 1942-1944, [w:] Zarys krajobrazu..., dz. cyt., s. 391.

93 Sprawę wywołano o godzinie 10. Przewodniczący: S.S.W. J. Polony, ławnicy T. Noga i St. Łopatka, prokurator wojewódzki St. Bartkowski, protokolant A. Kuźniar. Oskarżeni zostali doprowadzeni przez MO z więzienia w Montelupich. ANK 29/747/IV K 32/54, t. 2, Protokół rozprawy głównej przed Sądem Wojewódzkim w Krakowie Wydział Iv Karny, Kraków, 9.03.1954, k. 875-915.

${ }^{4}$ ANK 29/747/IV K 32/54, t. 2, Protokół rozprawy głównej przed Sądem Wojewódzkim w Krakowie Wydział Iv Karny, Kraków, 9.03.1954, k. 877.

${ }^{25}$ ANK 29/747/IV K 32/54, t. 2, Protokół rozprawy głównej przed Sądem Wojewódzkim w Krakowie Wydział Iv Karny, Kraków, 29.03.1954, k. 985. 
niemieckich nakazujące likwidowanie wszystkich napotkanych Żydów ${ }^{96}$. Swoje działania tłumaczyli także naciskiem osób trzecich i obawą przed represjami, jakie mogły spaść za karę na daną wieśs ${ }^{9}$. Argumentacja i usprawiedliwienia obu skazanych były typowe dla oskarżonych policjantów granatowych ${ }^{98}$. Obaj przyznali się do zarzucanych czynów, Błażej zaprzeczał jedynie, by brał udział w zabójstwie Messingerów ${ }^{99}$. Dlaczego Błażej nie przyznał się do udziału w tej zbrodni? Prawdopodobnie dlatego, że dokonana została bez udziału niemieckiego okupanta.

W aktach postępowań znalazło się też wiele bardzo interesujących danych związanych z pomocą udzielaną Żydom. Chociaż informacje zawarte w zeznaniach świadków są bardzo lakoniczne i nie pozwalają nam na zapoznanie się z motywami ratownictwa i całym dramatyzmem tych sytuacji, warto przypomnieć te przypadki. Wiemy więc, że rodzina Messingerów ukrywała się w domu rodziny Czajków w Kościelnikach. Według zeznań Franciszka Czajki przebywali u niego: „przez październik listopad i grudzień 194[2] r., a w styczniu 1943 r. zostali zabrani przez Niemców [przez granatowych policjantów]. Początkowo Żydzi ci mieszkali u mojej teściowej ${ }^{100}$, ale ponieważ tam było za ciasno, więc przenieśli się do mnie. Żydzi ukrywali się w spiżarni, a na obiad przychodzili do izby"101.

Potwierdzenie faktu pomocy udzielonej rodzinie Messingerów możemy znaleźć w innych protokołach przesłuchań świadków i zeznaniach złożonych podczas rozprawy ${ }^{102}$. Wiemy, że niektórzy mieszkańcy próbowali po-

${ }^{96}$ ANK 29/747/IV K 32/54, t. 2, Sentencja Wyroku, Kraków, 31.03.1954, k. 1008.

97 ANK 29/747/IV K 32/54, t. 2, Sentencja Wyroku, Kraków, 31.03.1954, k. 1007-1008. Sąd Wojewódzki zwrócił uwagę na jeszcze jeden motyw działalności oskarżonych: „którym można tłumaczyć jakkolwiek nie usprawiedliwiać faktów wykonywania bezpośrednio i własnymi rękami, niejako w zastępstwie Niemców, ich krwawej roboty. Oto likwidując znalezionych obywateli narodowości żydowskiej na miejscu bez odwoływania się do władz niemieckich, oskarżeni mieli możność osłonięcia tajemnicą przed tymi władzami osób przechowujących, ratując je w ten sposób przed represją". ANK 29/747/IV K 32/54, t. 2, Sentencja Wyroku, Kraków, 31.03.1954, k. 1010.

${ }_{98}$ Por. A. Skibińska, „Dostat 10 lat, ale za co?”..., dz. cyt., s. 391.

99 ANK 29/747/IV K 32/54, t. 2, Sentencja Wyroku, Kraków, 31.03.1954, k. 1007.

${ }^{100}$ Prawdopodobnie była to Katarzyna Kiania (Kianiowa). B. Trawiński, Przebłyski czarnej nocy..., dz. cyt., s. 71, 87, 95-96, 102-104, 108-111, 215.

${ }^{101}$ ANK 29/747/IV K 32/54, t. 2, Protokół rozprawy głównej przed Sądem Wojewódzkim w Krakowie Wydział Iv Karny [Zeznanie świadka Franciszka Czajki], 11.03.1954, k. 902-903.

102 „Wiadomo mi, że [w] gromadzie Branice w 1943 lub 1944 r. ukrywali się Żydzi u ob. Kalisza Franciszka”. ANK 29/747/IV K 32/54, t. 1, Protokół przesłuchania świadka T. Z., Ruszcza, 7.06.1953, k. 257-258. „[Messingerowie] W okresie okupacji hitlerowskiej na skutek utworzenia przez 
móc aresztowanym ${ }^{103}$. Stanisław Żurek zeznawał: „będąc w gminie, udałem się do powyższego aresztu i przez kraty w oknach starałem się porozmawiać z Messingerami. Ponieważ [gdy rozmawiałem] z nimi, ci skarżyli, iż są głodni, wówczas udałem się do Kurek Katarzyny, od której przyniosłem im jakieś pożywienie, a następnie dostarczyłem im do aresztu"104.

Co mogło mieć wpływ na podjęcie decyzji o udzieleniu pomocy? Jedynie w tych dwóch przypadkach znaleziono szczątkowe informacje na temat motywów. Decyzja o pomocy Żydom została podjęta ze względu na przyjaźnie lub znajomości łączące określonych ludzi jeszcze przed okupacją ${ }^{105}$. Według badaczy był to jeden $\mathrm{z}$ najważniejszych czynników ${ }^{106}$. Jednakże znajomości wśród gospodarzy nie zawsze gwarantowały szansę przeżycia.

W aktach sądowych znajdujemy przypadki zeznań Żydów, którzy przeżyli okupację. Od połowy 1942 r. do końca wojny na terenie gminy Ruszcza, w Kościelnikach i Wyciążu ukrywał się z żoną i dzieckiem Daniel Gelbart/ Gelbard. Według Trawińskiego Gelbard z żoną i córką przybył do Ruszczy po utworzeniu getta w Krakowie. Nie posiadał na terenie gminy znajomych

hitlerowców get[t]a wyjechali na teren Kościelnik, gdzie ukrywali się w domu Franciszka Czajki”. ANK 29/747/IV K 32/54, t. 1, Protokół przesłuchania świadka Romana Trauba, Kraków, 9.10.1953, k. 407-409.

${ }^{103}$ Bernard Trawiński wspominał o interwencji dziekana parafii rusieckiej księdza Katana, który udał się na posterunek policji i prosił o zwolnienie ujętych Żydów. B. Trawiński, Przebłyski czarnej nocy..., dz. cyt., s. 103.

${ }^{104} \mathrm{O}$ aresztowaniu rodziny Messingerów Stanisław Żurek dowiedział się od Katarzyny Kurek, właścicielki restauracji w Ruszczy. ANK 29/747/Iv K 32/54, t. 2, Protokół przesłuchania świadka Stanisława Żurka, Kraków, 8.01.1954, k. 623-627; ANK 29/747/Iv K 32/54, t. 2, Protokół rozprawy głównej przed Sądem Wojewódzkim w Krakowie Wydział Iv Karny [Zeznanie świadka Stanisława Żurka], 11.03.1954, k. 903.

${ }^{105}$ W relacji Franciszka Czajki czytamy: „W miesiącu październiku 1942 r., daty bliżej nie pamiętam, do domu mego w Kościelnikach przyszedł Traub Messinger wraz ze swą żoną Messingerową, prosząc mnie i żoną mą abyśmy pozwolili ukryć się w swoim domu, gdyż są prześladowani przez okupantów. Ponieważ żona moja dobrze czuła się z Messingerową, pozwoliłem im pozostać i zamieszkać u mnie". ANK 29/747/IV K 32/54, t. 2, Protokół przesłuchania świadka Franciszka Czajki, Kraków, 8.01.1954, k. 615-618. Podobne motywy znajdujemy w relacji Stanisława Żurka: „Wówczas udałem się do aresztu gminnego celem porozmawiania $\mathrm{z}$ w.w, gdyż ich dobrze znałem jako krewnych Traubów, a ponadto Messingerowie byli dla mnie bardzo dobrzy, tak jak ojciec dla swego dziecka, wobec czego chciałem się dowiedzieć, czy im czego nie potrzeba”. ANK 29/747/IV K 32/54, t. 2, Protokół przesłuchania świadka Stanisława Żurka, Kraków, 8.01.1954, k. 625.

${ }^{106}$ M. Urynowicz, Chaima Bermana życie i śmierć. Z dziejów pomocy Żydom, [w:] „Kto w takich czasach Żydów przechowuje?...” Polacy niosący pomoc ludności żydowskiej w okresie okupacji niemieckiej, red. A. Namysło, Warszawa 2009, s. 253. 
ani krewnych. Podczas Aktion Reinhard nie zgłosił się do transportu. Mieszkał w chłopskich domach, pracując jako krawiec ${ }^{107}$. Przebywał na Przylasku Wyciąskim u gospodarza: ,ja z żoną przebywaliśmy wówczas w komórce, gdzie wówczas mieszkaliśmy, zarabiając szyciem na życie [...]. Znałem również Bąka Franciszka, gdyż był sołtysem. Raz, gdy ukrywałem się, syn Bąka zauważył mnie w krzakach i dał znać ojcu, który przyniósł mi mleka. Później zawsze mi pomagał"108.

Z akt postępowań dowiadujemy się o działalności Jana Nowaka (wójt) i Antoniego Gawlika ${ }^{109}$ (pracował jak referent w wydziale administracyjnym) w gminie Ruszcza, którzy załatwiali Żydom aryjskie dokumenty: „wystawili kenkarty jako osoby narodowości polskiej”"110. Ich działalność potwierdzał w swoich wspomnieniach Bernarda Traub (Trawiński), wystawili oni również fałszywe karty rozpoznawcze dla niego i jego żony ${ }^{111}$.

Prześladowani Żydzi znajdowali pomoc w podkrakowskich dworach. Goszczono ich, traktując jak domowników, ale starano się wobec osób postronnych ukrywać ich pochodzenie ${ }^{112}$. W majątku rodziny Wodzickich ${ }^{113}$ w Kościelnikach, poza rodziną Zaciewskich i Wilczyńską ${ }^{114}$, których ujęto, we dworze, ukrywali się również inni. Z zeznań siostry hrabiego Stefana Wodzickiego

${ }^{107}$ B. Trawiński, Przebłyski czarnej nocy..., dz. cyt., s. 110-111.

${ }^{108}$ ANK 29/747/IV K 32/54, t. 2, Protokół rozprawy głównej przed Sądem Wojewódzkim w Krakowie Wydział Iv Karny [Zeznanie świadka Daniela Gelbarta], Kraków, 29.03.1954, k. 981-982.

${ }^{109}$ Antoni Gawlik, ur. 26 maja 1913 r. w Luczanowice pow. Kraków, syn. Jana i Wiktorii.

${ }^{110}$ ANK 29/747/IV K 32/54, t. 1, Protokół przesłuchania świadka K. Ż., Ruszcza, 6.07.1953, k. 262-263.

${ }^{111}$ B. Trawiński, Przeblyski czarnej nocy..., dz. cyt., s. 22-23.

${ }^{112}$ Zofia Wodzicka, według zeznań Taidy Woyczyńskiej: „Prowadziła ona we dworze coś w rodzaju pensjonatu. Między innymi gośćmi mieszkali tam Zaciewscy i Wilczyńska, którzy zajmowali pokoje na piętrze w moim sąsiedztwie. Żyłam z nimi dość blisko, grywaliśmy w bridża. Ktoś wspominał, że mają lewe papiery i że się ukrywają. Było przypuszczenie, że może są Żydami, ale nikt tego wyraźnie nie mówił”. ANK 29/747/Iv K 32/54, t. 2, Protokół rozprawy głównej przed Sądem Wojewódzkim w Krakowie Wydział Iv Karny [Zeznanie świadka Taidy Woyczyńskiej], Kraków, 11.03.1954, k. 894-895 [błędy w paginacji].

${ }^{113}$ Pałac Wodzickich w Kościelnikach.

${ }^{114}$ „Latem 1942 r. w domu brata mego zamieszkała również rodzina Zaciewskich składająca się z męża, żony i syna oraz pani Wilczyńska. W/w osoby zamieszkiwały w domu brata mego około jednego roku czasu”. ANK 29/747/IV K 32/54, t. 2, Protokół przesłuchania świadka Taidy Woyczyńskiej, Kraków, 31.12.1953, k. 599-602. 
Taidy Woyczyńskiej ${ }^{115}$ wiemy z całą pewnością, że na dworze w Kościelnikach: „ukrywali się miejscowi Żydzi bracia Traubowie. Trzymaliśmy ich na strychu w tajemnicy przed wszystkimi mieszkańcami dworu i ja sama nosiła[m] im jeść" ${ }^{116}$. O pozostałych przypadkach pomocy dowiadujemy się $\mathrm{z}$ lakonicznych informacji hrabiny Zofii Wodzickiej ${ }^{117}$. O spokrewnionej $\mathrm{z}$ rodziną Zaciewskich Wiktorii Słowikowej wiemy, że mieszkała w domu Władysława Bąka ${ }^{118}$.

Wśród osób ratujących Żydów była też rodzina Kaliszów: Anna ${ }^{119}$ i Franciszek $^{120} \mathrm{z}$ dziećmi. W swoim domu w Branicach ukrywali oni między innymi rodzinę Edwarda Rosmana/Rozmana (zmienił nazwisko na Różycki) ${ }^{121}$, która od lipca 1942 r. ukrywała się na terenie Kościelnik i Wyciąża. W 1943 r. rodzina ta przebywała u Sendorowej w Przylasku Rusieckim. Wiemy, że pomo-

${ }^{115}$ Taida Woyczyńska [Paulina Granowska-Woyczyńska z d. Wodzicka], ur. 17 października 1902 r., im. rodziców August i Felicja z d. Ponińska.

${ }^{116}$ Byli to bracia i siostra Bernarda Trauba Trawińskiego, którzy stamtąd przenieśli się do Katarzyny Kianiowej. B. Trawiński, Przebłyski czarnej nocy..., dz. cyt., s. 71. ANK 29/747/IV K 32/54, t. 2, Protokół rozprawy głównej przed Sądem Wojewódzkim w Krakowie Wydział Iv Karny [Zeznanie świadka Taidy Woyczyńskiej], Kraków, 11.03.1954, k. 894-895 [błędy w paginacji].

${ }_{117}$ „Na terenie mojego dworu w Kościelnikach ukrywałam bardzo dużo ludzi, z tego $15 \%$ było Żydów. [...] Jakoś w tym samym czasie przyjechał do nas do dworu adwokat Żyd wraz z rodziną, którzy także zachowywali się bardzo nieostrożnie, na skutek czego dałam im mieszkanie w Igołomii i oni się tam przechowali. [...] Altendorfowie mieszkali na wsi u chłopów”. ANK 29/747/IV K 32/54, t. 2, Protokół rozprawy głównej przed Sądem Wojewódzkim w Krakowie Wydział IV Karny [Zeznanie świadka Zofii Wodzickiej], Kraków, 11.03.1954, k. 905-907.

${ }^{118}$ „Po jakimś czasie Zacięscy sprowadzili do Kościelnik nie wiem skąd niejaką Wilczyńską i nieznaną mi z nazwiska kobietę, o której mówili, że jest to mamka [...] a owa mamka, o której ja przypuszczałam, że była matką Zacięskiego, zamieszkała na wsi u Bąka. Miała ona wydatne rysy semickie”. ANK 29/747/IV K 32/54, t. 2, Protokół rozprawy głównej przed Sądem Wojewódzkim w Krakowie Wydział Iv Karny [Zeznanie świadka Zofii Wodzickiej], 11.03.1954, k. 905-907. ANK 29/747/IV K 32/54, t. 1, Protokół przesłuchania świadka Władysława Bąka, Kraków, 8.07.1953, k. $322-324$.

${ }^{119}$ Anna Kalisz, ur. 26 lipca 1898 r. w Branicach, im. rodziców Maciej i Katarzyna.

${ }^{120}$ Franciszek Kalisz, ur. 27 lutego 1893 r. w Bronowicach, syn Jana i Katarzyny.

${ }^{121}$ ANK 29/747/IV K 32/54, t. 2, Protokół rozprawy głównej przed Sądem Wojewódzkim w Krakowie Wydział Iv Karny Zeznanie świadka Różycki Edward, 11.03.1954, k. 908-910. „W okresie okupacji hitlerowskiej w domu mym ukrywało się kilka osób narodowości żydowskiej, którzy byli prześladowani przez hitlerowskiego okupanta. Między innymi ukrywał się Rosman Edward, obecne jego nazwisko Różycki, wraz z całą rodziną i siostrą jego wraz z 4-letnim dzieckiem, której nazwiska nie znałem". ANK 29/747/IV K 32/54, t. 1, Protokół przesłuchania świadka Franciszka Kalisza, Kraków, 9.10.1953, k. 403-406. 
cy im udzielił również Maciej Jeleń ${ }^{122}$. Rosman ukrywał się z żoną Stefanią i synami Leopoldem i Adamem oraz córką Stanisławą w różnych miejscach, kilkakrotnie nocowali w plebańskiej stodole i regularnie otrzymywali od ks. proboszcza Leona Katany wsparcie żywnościowe ${ }^{123}$. Rodzina ta przetrwała okupację dzięki pomocy Julii Piękosz z Borzęcina ${ }^{124}$.

Niewątpliwie część funkcjonariuszy granatowej policji uległa demoralizacji, a część paraliżował strach przed sprzeciwem. Jednakże znamy przypadki chronienia lub ostrzegania Żydów przed grożącym im ujęciem ${ }^{125}$ : „W miesiącu maju 1943 r. w godzinach wieczornych przyszedł do domu [Kaliszów] naszego tenże komendant [Głuszek Franciszek], który przyszedł oświadczyć nam, [...] że w najbliższym czasie na terenie Branic władze hitlerowskie będą przeprowadzały łapanki za ukrywającymi się w terenie Żydami i ludzie, którzy w waszym domu się ukrywają, aby za ten okres czasu usunęły się z naszego domu. Wobec tego osoby ukrywające się u nas w domu wyszły, a pozostała jedynie jedna chora kobieta z dzieckiem"126.

O przebiegu dalszych dramatycznych wydarzeń i represjach, jakie dotknęły tę rodzinę, wiemy z relacji córki Kaliszów Józefy Matuszczyk ${ }^{127}$ : „po przyjściu okrążyli dom i 2-ch Niemców weszło do mieszkania, inni na strych, skąd zabrali Wjscheldównę [Tonia Weisfeld/Weisman], żydówkę ukrywającą się u nas w domu. 2-ch niemców przez cały czas biło mnie kolbami, a Błażej do nich mówił, żeby mnie bić, i pytał się, gdzie jest więcej żydów, później

${ }^{122}$ „Niepamiętnej mi daty gdzieś w 43 roku mówiła mi kuzynka, że przyszedł «Młotek» t.j. Rosman, żeby go $\mathrm{z}$ rodziną przechować. Wtedy ja zrobiłem $\mathrm{w}$ stodole $\mathrm{z}$ łat budę na około $2 \mathrm{~m} 2$. Kiedy Rosman tam przyszedł, nie wiem, wiem, że kuzynka nosiła im tam jeść. [...] Słyszałem od Rosmana potem, że Błażej, gdy przyszedł za stodołę, wołał do ukrywających się, żeby wyszli, a gdy oni go błagali, kazał im uciekać. [...] Wiem, że Rosman u policji okupywał się”. ANK 29/747/ IV K 32/54, t. 2, Protokół rozprawy głównej przed Sądem Wojewódzkim w Krakowie Wydział IV Karny [Zeznanie świadka Macieja Jelenia], 29.03.1954, k. 982-983.

${ }^{123}$ Ten jest z ojczyzny mojej. Polacy z pomoca Żydom 1939-1945, oprac. W. Bartoszewski, Z. Lewinówna, Kraków 2013, s. 608.

${ }^{124} 7$ lipca 1966 r. Instytut Yad Vashem nadał Julii Piękosz oraz jej córce Emilii Hynek (z domu Piękosz) tytuł Sprawiedliwych wśród Narodów Świata. Księga Sprawiedliwych wśród Narodów Świata. Ratujący Żydów podczas Holocaustu. Polska, red. I. Gutman, Kraków 2009, s. 557.

${ }^{125}$ Trawiński pisał o policjancie granatowym Romanie Warso, który osobiście ostrzegał Żydów przed grożącym im ujęciem. B. Trawiński, Przebłyski czarnej nocy..., dz. cyt., s. 71.

${ }^{126}$ ANK 29/747/IV K 32/54, t. 1, Protokół przesłuchania świadka Mieczysławy Kalisz, Kraków, 8.07.1953, k. 389-393.

${ }^{127}$ Józefa Matuszczyk, ur. 6 czerwca 1923 r. w Branicach, im. rodziców Franciszek i Anna z d. [Dubas/Dubaś]. 
mówił do nich, żeby mnie zastrzelić. [...] Jeden z Niemców doprowadził mnie do dołu i powiedział mi, że tu będę leżeć, na skutek interwencji komendanta [Głuszka Franciszka] nie zastrzelili mnie. [...] w wyniku tortur byłam w szpitalu przez 6 tygodni. Przez dłuższy czas Błażej przyjeżdżał do nas o każdej porze dnia i chciał, jak opowiadał do nas, [że] zastrzeli matkę, która się ukrywała. $\mathrm{Na}$ drugi dzień po zastrzeleniu Wajscheldowej Błażej zastrzelił jej syna u nas w ogrodzie, który liczył około 4 do 5 lat, ojciec pochował go w tym samym miejscu, gdzie matka"128.

Jak pokazywał ten przykład, zagrożenie było realne. Ryzyko śmierci i represji z rąk Niemców dotyczyło przede wszystkim osób udzielających w swych domach schronienia Żydom. Jednakże Polacy pomagający Żydom ryzykowali nie tylko życiem swojej rodziny, ale również sąsiadów ${ }^{129}$.

\section{Podsumowanie}

Dokumentacja powojennych postępowań karnych wszczętych na podstawie dekretu sierpniowego, pomimo swojej niewystarczalności ${ }^{130}$, procesowego charakteru i celu, jest cennym źródłem do badań nad negatywnymi zachowaniami podczas okupacji, przy czym, jak podkreślała Elżbieta Rączy, w wielu przypadkach ich sprawcami nie były osoby oskarżone ${ }^{131}$. W świetle omówionej dokumentacji sądowej policjanci granatowi zostali skazani za popełnione przestępstwa okupacyjne.

${ }^{128}$ ANK 29/747/IV K 32/54, t. 1, Protokół przesłuchania świadka Józefy Matuszczyk, Kraków, 8.07.1953, k. 357-359.

${ }^{129}$ Sołtys Wincenty Adamski zeznawał: „Niemcy mówili, że gdy znajdą Żyda we wsi, to ludzie z 10 domów będą rozstrzelani. [...] Na zebraniach w gminie mówiono nam, żeby donosić Żydów ukrywających się w gromadzie. Afisze na ten temat nie były u nas wcale rozlepiane. O wystrzelaniu ludzi z 10 domów mówili Niemcy nie tylko do mnie, ale do wszystkich sołtysów”. ANK 29/747/IV K 32/54, t. 2, Protokół rozprawy głównej przed Sądem Wojewódzkim w Krakowie Wydział Iv Karny [Zeznanie świadka Wincentego Adamskiego], Kraków, 11.03.1954, k. 901-902.

${ }^{130}$ Uwagi krytyczne dotyczące wykorzystania akt procesów sierpniowych jako źródła historycznego zob. m.in.: S. Salmonowicz, Tragiczna noc okupacji niemieckiej. O problematyce „kolaboracji oddolnej” w Generalnym Gubernatorstwie (1939-1945), „Studia Iuridica Toruniensia” (2012) t. 11, s. 146-172; W. J. Muszyński, Holocaust stereotypami i wrażeniami pisany, „Glaukopis” (2011) nr 21-22, s. 321-324; B. Musiał, Judenjagd - „umiejętne działanie czy zbrodnicza perfidia, „Dzieje Najnowsze” 43 (2011) nr 2, s. 159-170; polemika zob. J. Grabowski, Rżnięcie nożem po omacku czyli polemika historyczna à la Bogdan Musiał, „Dzieje Najnowsze” 43 (2011) nr 4, s. 163-177.

${ }_{131}$ E. Rączy, Negatywne postawy..., dz. cyt., s. 266. 
Analizowana sprawa jest przykładem postępowania, w którym na etapie stadium przygotowawczego i sądowego zebrano bogaty materiał dowodowy. Przy okazji przesłuchań świadków pojawiają się informacje na temat ratowania Żydów na terenach wiejskich. Informacje te są szczególnie ciekawe, ponieważ w warunkach okupacji niemieckiej zaangażowani musieli pozostawiać jak najmniej śladów po swojej działalności. Ponadto na wsi mamy głównie do czynienia z pomocą osób indywidualnych, które nie były wspierane przez organizacje i nie pozostawiły po swojej działalności bogatej bazy źródłowej ${ }^{132}$.

Nie ma powodu, by tego źródła nie wykorzystać do dalszych badań nad przypadkami pomocy udzielanej ludności żydowskiej. Informacje o pomocy znajdujące się w zachowanej dokumentacji są niewielką pozostałością wszystkich przypadków ${ }^{133}$. Zagadnienie ratowania Żydów wymaga przeprowadzenia badań podstawowych, aby możliwe było dokonanie syntezy ${ }^{134}$. Konieczne jest również oszacowanie liczby Polaków, którzy ponieśli śmierć lub spotkali się $\mathrm{z}$ inną formą represji za pomoc udzielaną Żydom.

Niniejszy artykuł jest również przyczynkiem do dalszych badań nad procesem rozliczenia przestępstw okupacyjnych popełnionych przez niektórych policjantów granatowych. Jest to wezwanie stojące przed badaczami zajmującymi się tymi zagadnieniami. Szersza analiza akt postępowań karnych byłych policjantów granatowych może w przyszłości pozwolić odpowiedzieć na pytania o skalę zaangażowania przez Niemców policji granatowej w proces eksterminacji Żydów oraz ich wyłapywanie. Wiele pracy czeka, by w zadowalający sposób odpowiedzieć na pytania o poznanie mechanizmów, rozkazów, skali zjawiska, stopnia gorliwości w wykonywaniu służbowych poleceń oraz represji za uchylanie się od nich ${ }^{135}$.

${ }^{132}$ Por. Z. Schnepf-Kołacz, Pomoc Polaków dla Żydów..., dz. cyt., s. 195-198.

${ }^{133}$ M. Urynowicz, Zorganizowana i indywidualna pomoc Polaków dla ludności żydowskiej eksterminowanej przez okupanta niemieckiego w okresie drugiej wojny światowej, [w:] Polacy i Żydzi pod okupacją niemiecką 1939-1945. Studia i materiały, red. A. Żbikowski, Warszawa 2006, s. 242-243.

${ }^{134}$ Sebastian Piątkowski wskazywał na akta procesów sierpniowych jako zawierających wiele bogatych merytorycznie i interesujących danych, mogących uzupełnić naszą wiedzę o realiach lat okupacji. Zwracał uwagę, że akta postępowań karnych są również źródłem, które można wykorzystać do tematu pomocy udzielanej Żydom w okresie okupacji. S. Piątkowski, Oprawcy, prześladowcy, ratownicy. Problematyka Zagłady w aktach radomskiej ekspozytury Prokuratora Specjalnego Sądu Karnego w Lublinie, „Zagłada Żydów. Studia i Materiały” (2008) nr 4, s. 485-498.

${ }^{135}$ Wyniki badań zrealizowane w ramach tematu „Powojenne akta sądowe z województwa krakowskiego jako źródło do badań postaw chłopów wobec Żydów w czasie Zagłady” zostały sfinansowane $\mathrm{z}$ dotacji celowej na naukę przyznanej przez MNisw w roku 2017. 


\section{Abstrakt}

Niniejszy artykuł koncentruje się na szczegółowej źródłowej rekonstrukcji przebiegu postępowań karnych prowadzonych w latach 1947-1955 w sprawie zbrodni popełnionych przez funkcjonariusza policji Jana Błażeja. Celem niniejszej pracy jest analiza powojennego materiału dochodzeniowo-śledczego. Przestępczość omawiana $\mathrm{w}$ artykule miała miejsce $\mathrm{w}$ wielu wioskach, które podczas okupacji znajdowały się na terenie dystryktu krakowskiego. Uzyskanie pełnego obrazu wzajemnych uwarunkowań i mechanizmów działania sądownictwa, w którym funkcjonowali oskarżeni, oskarżający i sędziowie wymaga sięgnięcia po różnorodny, dostępny i zachowany materiał archiwalny. Po wojnie sprawców osądzono na podstawie dekretu z dnia 31 sierpnia $1944 \mathrm{r}$. W zachowanej dokumentacji można znaleźć interesujące materiały związane z Holokaustem.

\section{SŁOWA KLUCZOWE}

dekret sierpniowy, przestępstwa okupacyjne, stosunki polsko-żydowskie

\section{Abstract}

Criminal proceedings conducted in the years 1947-1955 in the crimes committed by the occupation Police Navy officer Jan Blazej. Contribution to the study of Polish-Jewish relations

This article concentrates on detailed reconstruction of the course of criminal proceedings conducted in the years 1947-1955 in the crimes committed by Police officer - Jan Błażej. The paper's aim is to analysis of the post-war investigation and trial materials. The crime discussed in the article took place in many villages which during occupation were located in the Cracow district. Getting the full picture of mutual conditions and mechanisms of judiciary work, in which the defendant, prosecution and judges were present, requires taking diverse, available and preserved archival materials. After the war the perpetrators were indicated on the basis of the Decree of 31 August 1944. In the preserved files one can find interesting materials related to the Holocaust.

\section{KEY WORDS}

Polish-Jewish relations, the "August Decree", the occupation crimes 


\section{BIBLIOGRAFIA}

\section{Źródła}

\section{Archiwum Narodowe w Krakowie}

ANK 29/I 2 Zg 1054/46 [Akta o uznanie za zmarłych Zofii, Leona i Józefa Messingerów]. AN K 29/747/IV K 32/54 [Akta sprawy karnej przeciwko Janowi Błażejowi i Ludwikowi Guzkowi].

ANK 29/747/IV K 228/57 [Akta sprawy karnej przeciwko Franciszkowi Głuszkowi i Hipolitowi Kosteczce].

\section{Instytut Pamięci Narodowej Oddział w Krakowie}

IPN Kr 502/3496 Akta w sprawie przeciwko: Jerzy Błażej, podejrzanego o to, że jako funkcjonariusz tzw. granatowej policji, dokonał kilkunastu zabójstw osób narodowości żydowskiej, tj. o czyn z art. 1 Dekretu z dnia 31.08.1944 r.

\section{Opracowania}

Amtliches Gemeinde- und Dorfverzeichnis für das Generalgouvernement auf Grund der Summarischen Bevölkerungsbestandsaufnahme am 1. März 1943, Krakau 1943.

Borowiec J., Metody śledcze stosowane podczas przestuchań przez pracowników urzędów bezpieczeństwa publicznego, „Studia Rzeszowskie” 2 (1995), s. 45-58.

Borowiec J., Zbrodnie popelnione na Żydach przez oddział Gwardii Ludowej „Iskra” $w$ świetle dokumentów sądowych, [w:] Z dziejów stosunków polsko-żydowskich $w$ XX wieku, red. E. Czop, E. Rączy, Rzeszów 2009, s. 73-85.

Chorązki M., Ziemianie wobec wojny. Postawy właścicieli ziemskich województwa krakowskiego w latach 1939-1945, Kraków 2010.

Grabowski J., Judenjagd. Polowanie na Żydów 1942-1945. Studium dziejów pewnego powiatu, Warszawa 2011.

Grabowski J., Rżnięcie nożem po omacku czyli polemika historyczna à la Bogdan Musiał, „Dzieje Najnowsze” 43 (2011) nr 4, s. 163-177.

Grabowski J., Społeczność wiejska, policja granatowa i ukrywający się Żydzi: powiat Dąbrowa Tarnowska 1942-1945, [w:] Zarys krajobrazu. Wieś polska wobec zagłady Żydów 1942-1945, red. B. Engelking, J. Grabowski, Warszawa 2011, s. 139-170.

Grabowski J., Strażacy, wiejska straż nocna i granatowa policja a zagłada Żydów na obszarach wiejskich $w$ dystrykcie krakowskim, [w:] Zagłada Żydów na polskiej prowincji, red. A. Sitarek, M. Trębacz, E. Wiatr, Łódź 2012, s. 245-264.

Hempel A., Pogrobowcy klęski. Rzecz o policji „granatowej” w Generalnym Gubernatorstwie 1939-1945, Warszawa 1990. 
Ignatiew R., Komentarz do art. 1 pkt 1 dekretu $z$ dnia 31.08.1944 r. o wymiarze kary dla faszystowsko-hitlerowskich zbrodniarzy winnych zabójstw i znęcania się nad ludnościa cywilna i jeńcami oraz dla zdrajców Narodu Polskiego (tekst jednolity Dz.U. 1946, nr 69, poz. 377, z późn. zm.), [w:] Zbrodnie przeszłości. Opracowania i materiały prokuratorów IPN, red. R. Ignatiew, A. Kury, t. 2: Ludobójstwo, Warszawa 2008, s. 104-116.

Kobierska-Motas E., Ekstradycja przestępców wojennych do Polski z czterech stref okupacyjnych Niemiec: 1946-1950, cz. 2, Warszawa 1992.

Krochmal A., Pomoc Żydom w czasie II wojny światowej $w$ świetle polskich i niemieckich źródeł archiwalnych, [w:] Z dziejów stosunków polsko-żydowskich w xx wieku, red. E. Czop, E. Rączy, Rzeszów 2009, s. 38-53.

Ksiega Sprawiedliwych wśród Narodów Świata. Ratujący Żydów podczas Holocaustu. Polska, red. I. Gutman, Kraków 2009.

Kubicki L., Zbrodnie wojenne w świetle prawa polskiego, Warszawa 1963.

Leociak J., Literatura dokumentu osobistego jako źródła do badań nad zagłada $Z$ Zydów. Rekonesans metodologiczny, „Zagłada Żydów. Studia i materiały” (2005) nr 1, s. $13-31$.

Lityński A., Na drodze ku nowej procedurze karnej: o postępowaniu przygotowawczym w latach 1943-1950, [w:] Przestępstwa sędziów i prokuratorów w Polsce lat 1944-1956, red. W. Kulesza, A. Rzepliński, Warszawa 2001, s. 49-66.

Lityński A., O prawie i sądach początków Polski Ludowej, Białystok 1999.

Musiał B., Judenjagd - umiejętne działanie czy zbrodnicza perfidia, „Dzieje Najnowsze” 43 (2011) nr 2, s. 159-170.

Muszyński W. J., Holocaust stereotypami i wrażeniami pisany, „Glaukopis” (2011) nr 21-22, s. 320-327.

Pasek A., Przestępstwa okupacyjne w polskim prawie karnym z lat 1944-1956, Wrocław 2002.

Piątkowski S., Oprawcy, prześladowcy, ratownicy. Problematyka Zagłady w aktach radomskiej ekspozytury Prokuratora Specjalnego Sądu Karnego w Lublinie, „Zagłada Żydów. Studia i Materiały" (2008) nr 4, s. 485-498.

Rączy E., Negatywne postawy mieszkańców powiatu przemyskiego podczas niemieckiej okupacji w świetle powojennych procesów, [w:] Miasta i ludzie. Sacrum i profanum. Studia $z$ dziejów społecznych i gospodarczych dedykowane Profesorowi Jerzemu Motylewiczowi, red. P. Grata, B. Lorens, Rzeszów 2013, s. 265-279.

Rączy E., Zagłada Żydów w dystrykcie krakowskim w latach 1939-1945, Rzeszów 2014. Rzepliński A., Ten jest z ojczyzny mojej? Sprawy karne oskarżonych o wymordowanie Żydów w Jedwabnem w świetle zasady rzetelnego procesu, [w:] Wokół Jedwabnego, red. P. Machcewicz, K. Presak, t. 1: Studia, Warszawa 2002, s. 353-459. 
Salmonowicz S., Tragiczna noc okupacji niemieckiej: o problematyce „kolaboracji oddolnej” w Generalnym Gubernatorstwie (1939-1945), „Studia Iuridica Toruniensia” (2012) t. 11, s. 146-172.

Schnepf-Kołacz Z., Pomoc Polaków dla Żydów na wsi w czasie okupacji niemieckiej. Próba opisu na przykładzie Sprawiedliwych wśród Narodów Świata, [w:] Zarys krajobrazu. Wieś polska wobec zagłady Żydów 1942-1945, red. B. Engelking, J. Grabowski, Warszawa 2011, s. 195-258.

Skibińska A., „Dostał 1 o lat, ale za co?”. Analiza motywacji sprawców zbrodni na Żydach na wsi kieleckiej w latach 1942-1944, [w:] Zarys krajobrazu. Wieś polska wobec zagłady Żydów 1942-1945, red. B. Engelking, J. Grabowski, Warszawa 2011, s. 313-444.

Skibińska A., Źródła do badań nad zagładą Żydów na okupowanych ziemiach polskich. Przewodnik archiwalno-bibliograficzny, Warszawa 2007.

Śmietanka-Kruszelnicki R., Protokół przesłuchania jako źródło historyczne, „Pamięć i Sprawiedliwość" 2 (2003) nr 1(3), s. 199-207.

Ten jest z ojczyzny mojej. Polacy z pomoca Żydom 1939-1945, oprac. W. Bartoszewski, Z. Lewinówna, Kraków 2013.

Trawiński B., Przeblyski czarnej nocy. Wspomnienia 1939-1945, Kraków 2011.

Urynowicz M., Chaima Bermana życie i śmierć. Z dziejów pomocy Żydom, [w:] „Kto w takich czasach Żydów przechowuje?..." Polacy niosący pomoc ludności żydowskiej w okresie okupacji niemieckiej, red. A. Namysło, Warszawa 2009, s. 252-266.

Urynowicz M., Zorganizowana i indywidualna pomoc Polaków dla ludności żydowskiej eksterminowanej przez okupanta niemieckiego w okresie drugiej wojny światowej, [w:] Polacy i Żydzi pod okupacja niemiecka 1939-1945. Studia i materiały, red. A. Żbikowski, Warszawa 2006, s. 209-364.

Wojciechowska J., Przestępcy hitlerowscy przed specjalnym sądem karnym $w$ Toruniu (1945-1946), Toruń 1965. 